Article

\title{
Social Innovation, Societal Change, and the Role of Policies
}

\author{
Robert Lukesch ${ }^{1}$, Alice Ludvig ${ }^{2}$, , Bill Slee ${ }^{3}$, Gerhard Weiss ${ }^{2, *}$ (D) and Ivana Živojinović ${ }^{2}$ (D) \\ 1 ÖAR GmbH, Hirzenriegl 55, A-8350 Fehring, Austria; lukesch@oear.at \\ 2 Institute of Forest, Environmental and Natural Resource Policy, University of Natural Resources and Life Sciences, \\ Vienna (BOKU) and European Forest Institute, Forest Policy Research Network, Feistmantelstrasse 4, A-1180 Vienna, \\ Austria; alice.ludvig@boku.ac.at (A.L.); ivana.zivojinovic@boku.ac.at (I.Ž.) \\ 3 The Rural Development Company, 4 Manse Lane Tannadice, Forfar DD8 3TA, UK; Bill.Slee@hutton.ac.uk \\ * Correspondence: gerhard.weiss@boku.ac.at
}

Received: 1 August 2020; Accepted: 3 September 2020; Published: 9 September 2020

check for updates

\begin{abstract}
Political frameworks and policies have a strong influence on the institutional ecosystem and on governance patterns, which in turn shape the operational space of civil society initiatives. This article aims to explore the social and institutional conditions and policy initiatives that foster or hinder social innovation and the pathways leading from social innovation to institutional change through to actual impacts on policies and political frameworks, in order to understand how policymakers can encourage and enable social innovation. The article builds on an extensive empirical background to develop a heuristic model to facilitate decision making for a policy environment propitious for the emergence of social innovation. The resulting model sets up a triadic configuration of (i) a committed core of key actors, (ii) the benevolent shadow of hierarchy represented by public actors, and (iii) multifunctional and malleable intermediary support structures for a successful development of social innovation initiatives. The model is discussed and validated by reference to three in-depth case studies from differing institutional settings. We conclude that policy should recognize that social innovation will achieve most when the triadic relationships between the state, intermediary organizations, and local actors are working together synergistically.
\end{abstract}

Keywords: civil society actors; governance; policy impact; rural areas; Europe

\section{Introduction}

Social innovation has hitherto been defined in various ways, but there is a common understanding that it connects to social change emanating from people's everyday interactions, ascending, spreading, and gaining traction and visibility from often inconspicuous beginnings, until it reshapes the diverse ways in which social groups and communities deal with social, economic, or environmental challenges. Both social and political aspects resonate in the term "social innovation". It originates from academic discourse rather than from everyday language [1], but the actual relationship between social innovation initiatives on one hand and political frameworks and policies on the other has not been sufficiently investigated so far, particularly not for rural areas where institutional thickness is likely to be less than in urban environments [2]. Social innovation and its drivers have been studied in rural areas far less than in urban environments or in the context of urbanization [3], but there is consensus on the need to support the design and implementation of social innovations as a response to existing complex problems rural communities are facing [4,5]. This research gap has been addressed by the EU research project SIMRA (Social Innovation in Marginalized Rural Areas) [6], which produced a wealth of empirical material and created the possibility to explore the policy implications of social 
innovation in rural areas, the results of which can be tested and further developed on the basis of additional empirical findings.

Based on the assumption that social innovation is both a formative influence on policy and social change and a response to it [7], this article focuses on the following specific questions:

(i) What are the social and institutional conditions and policy initiatives that foster or hinder social innovation?

(ii) How can policymakers encourage, enable, and promote social innovation, and utilize social innovation to achieve better results in developing rural areas?

A brief presentation of the methodology (Section 2) is followed by an exploration of the theoretical background and a recall of the main conclusions of the SIMRA project regarding the policy implications of social innovation (Section 3). Building on these conclusions, the authors proceed to present a heuristic model for understanding and analyzing the role of policies and institutional frameworks in social innovation and social change in the context of rural areas in Section 4. The model provides the analysis grid for three case studies, which are presented and summarized in Section 5. The wider applicability of the model is discussed in Section 6, and, finally, the authors draw conclusions on the research questions in Section 7.

\section{Methods}

Our methodological approach consists of two steps: (i) based on theoretical and empirical knowledge, a conceptual model is developed, by means of which practical examples can be analyzed; and (ii) this model is used for an analysis of three detailed case studies of social innovation in rural areas, and thereby validated.

\subsection{Developing a Heuristic Model for Analysing Policies and Social Innovation}

The model mainly draws on neo-institutionalist approaches, social systems theory, transition theory, and other sources that have influenced the European interdisciplinary research project SIMRA. In recognition of the seminal role of the SIMRA project in the theoretical framing [8] and the development of analytical tools to evaluate and understand social innovation in rural areas [9-11], exemplified by means of eleven in-depth case studies [12,13], we briefly recall the conclusions on the role of policies regarding social innovation $[14,15]$. The authors of this article have been responsible for this analysis in the SIMRA project [7,16-18] and for according policy recommendations for the support of social innovation in rural areas [19-21]. In the attempt to give policy makers and advisers practical orientation, in this paper the authors condense these previous conclusions into a heuristic model of three interrelated factors, which they term the "triad of actors".

\subsection{Applying the Heuristic Model in Three In-depth Case Studies of Social Innovation in Rural Areas}

In order to test the applicability of the developed model in various types of social innovations and political-institutional settings, the authors analyzed three social innovation initiatives by use of this model. Based on the intimate knowledge of the authors, those examples reflect different European political-institutional and economic settings. One (a) is located in an EU Member State (Austria) with a well-developed social security and welfare system, in which the state is acknowledged as the primary actor; another is (b) in a country more markedly linked with the neoliberal turn towards free markets and a small state, and is more reliant on a charitable and third sector tradition (UK/Scotland); and the third is (c) in a South-Eastern European country (Serbia) with a socialist past, having gone through war and disruptive transformation, with an economy still in transition and a people profoundly mistrusting public institutions (Table 1):

a. The initiative Apprentice Worlds represents a social innovation promoted by a LEADER Local Action Group in a disadvantaged rural area in Austria. LEADER is a European Union structural policy instrument for supporting rural development. The initiative aims at closing the gap 
between rural youth just about to leave the education system and the local economy desperately seeking junior staff and skilled workers. This case study was conducted in the course of the Austrian research project SILEA (Social Innovation in LEADER 2014-2020: LAG Zeitkultur Oststeirisches Kernland 2020). The SILEA research team analyzed available documents and carried out interviews with eight interlocutors: four current or former project managers, the LAG manager, one participating entrepreneur, one representative from the regional Chamber of Commerce, and one from the State government. Finally, a focus group with representatives from other social innovation initiatives was organized. The comprehensive case study [22] followed a format applied to all the eight in-depth case studies of SILEA, inspired by the innovation biography methodology [23].

b. Braemar Community Hydro was promoted by a Community Development Trust in Scotland/UK. This small-scale hydro-power plant is a community-owned enterprise and community benefit society. This case has been studied as a secondary case study in the frame of SIMRA [24] and was not included in the SIMRA cross-case analysis [14]. For the research, a focus group discussion with the chair of the community enterprise, those responsible for the financial and technical development of the hydro power plant, and a project officer (4 persons) and interviews with the core and network actors of the project were conducted (7 persons), following the methodology for the detailed analysis of social innovations developed for the SIMRA project $[9,25]$.

c. The Agricultural Development Fund Fenomena (DAFF) was established by the Citizens Association Fenomena. It operates as a business angel in support of integrated, sustainable agriculture in Serbia. This case study has been conducted as a primary source for this article. Three interviews were conducted, one with the project manager of the Fenomena Association, one with the head of a government unit supporting the initiative, and one with the representative of the coalition for the development of the solidarity economy, which is an informal network of organizations that support the development of solidarity entrepreneurship. Parts of the data from these interviews were used in another publication focusing on the analysis of institutional challenges confronting social innovation in Serbia [26].

Table 1. The three case studies used for validating the conceptual model.

\begin{tabular}{|c|c|c|c|}
\hline Case Study & Promoter & Location & $\begin{array}{l}\text { Characterization of the } \\
\text { Social Innovation }\end{array}$ \\
\hline Apprentice Worlds & $\begin{array}{l}\text { LAG Zeitkultur } \\
\text { Oststeirisches Kernland, } \\
\text { a public-private } \\
\text { partnership according to } \\
\text { LEADER }\end{array}$ & Austria (Steiermark) & $\begin{array}{l}\text { Local partnership (Local } \\
\text { Action Group according } \\
\text { to the LEADER } \\
\text { approach) acting as a } \\
\text { social entrepreneur in } \\
\text { the career orientation of } \\
\text { school-leavers. }\end{array}$ \\
\hline $\begin{array}{c}\text { Braemar Community } \\
\text { Hydro }\end{array}$ & $\begin{array}{l}\text { Braemar Community } \\
\text { Limited, a Local } \\
\text { Development Trust }\end{array}$ & UK (Scotland) & $\begin{array}{c}\text { Local renewable energy } \\
\text { project incubated by a } \\
\text { community development } \\
\text { enterprise. }\end{array}$ \\
\hline $\begin{array}{c}\text { Agricultural Development } \\
\text { Fund Fenomena }\end{array}$ & $\begin{array}{l}\text { Fenomena Assocation, a } \\
\text { non-governmental } \\
\text { association. }\end{array}$ & Serbia (Kraljevo area) & $\begin{array}{l}\text { Revolving fund run by a } \\
\text { civic association acting } \\
\text { as a business angel. }\end{array}$ \\
\hline
\end{tabular}

Source: Own design.

The three case studies, presented in Section 5, were analyzed by use of the heuristic model set out under Section 4. 


\section{Theoretical Background: Social Innovation and Policies—a Delicate Relationship}

\subsection{Social Innovation in the Sustainability Debate}

Social innovation is an idea with many roots, in the fuzzy zone where notions of "social change" $[27,28]$ and "innovation" $[29,30]$ intersect. It occupies an expanding niche, especially where weak markets and declining public services meet growing citizen interest in place-based development. In reference to the research project SIMRA, the authors consider social innovation as:

"the reconfiguring of social practices, in response to societal challenges, which seeks to enhance outcomes on societal well-being and necessarily includes the engagement of civil society actors". [31] (p. 4)

In contrast to social change or innovation without an adjectival descriptor, there is a normative reverberation in the notion of social innovation, just as is the case with sustainability, which implies the continued existence of humankind as an intrinsic value. The definition of social innovation cited above explicitly includes an "outcome on societal well-being". Thus, social innovation implies that either the intent, the process, the practice, or the factual results feature a desire for some betterment compared to the previous state or to the outcome of the (in most cases imagined) counterfactual, which would be the absence of such change. "Societal well-being" points toward betterment for the many, which implies that the improvement of life conditions, especially of vulnerable groups, is supposed to positively affect society at large. Consequently, the orientation of social innovation towards common well-being reflects a point of convergence with sustainability:

"Social innovation has been the anonymous bedrock of global sustainable development for many years, but mainly disguised by a plethora of other labels". [32] (p. 40)

Obviously, the notion of social innovation blurs into what is epitomized as social change, or more precisely societal change [33]. The difference between "social" and "societal" may lie in the purpose and granularity of perception. Social innovation is perceptible as a variation, a difference, a local response to a wake-up jolt, while adopting a close-up look on social phenomena occurring over a relatively short period of time. Societal change is perceptible from a more distant vantage point, as a cumulation of social change phenomena on an aggregated scale. As stated above, the notion of societal change is a value-neutral term, whereas social innovation is value laden. Social innovation initiatives can therefore be considered as molecular processes coalescing into societal change towards more sustainable societies. As the social innovation discourse is rife with expectations towards more sustainable and cohesive societies through inclusive practices, coproduction and pro-active grassroots initiatives [34], we argue that more theoretical and empirical work is needed to help social innovation develop into an effective policy tool in order to become a useful concept for policy makers.

\subsection{Policies and Political Frameworks}

Although the term policy can be used in public, corporate, and other societal spheres, in this article it is used as a synonym for public policies. Any policy can be considered as a plan of action [16]. Policy programs are needed to turn plans into reality, using policy instruments for delivery and implementation. There are three kinds of policy instruments: (i) legal policy instruments, e.g., laws and regulations; (ii) monetary policy instruments, e.g., subventions, funding, access to cheap loans, or tax reduction; (iii) informational policy instruments, e.g., information campaigns, support through education and training, or awareness rising and understanding [16] (p. 3). A similar triad distinguishes policies as "sticks, carrots, and sermons" [35]. "Sticks" are limiting the scope of actions by imposing sanctions on undesirable behaviors. "Sticks" mostly come along as laws and regulations. Other laws and regulations, but rather in the form of monetary and other incentives, are of the "carrot" type. Their aim is to reward and thereby reinforce behavioral patterns that appear to go in the direction wanted by the legislator. "Sermons" are explanatory and essentially exhortatory and motivating, such as the UN Agenda 2030, bestowing the ethical fundamentals and logical coherence on the other two instruments, but "sermons" can also be delivered locally by advisers and change agents, such as local zero carbon or food sovereignty strategies. 


\subsection{Structure and Agency: The SIMRA model of Social Innovation}

Since policies are plans of actions, they only flesh out as implementation processes. Processes derive from, unfold within and through, and feed back into structures. We call these structures "political frameworks". Thus, policies and political frameworks relate to one another like processes and structures, interlinked by the notion of "organization" or "configuration of relationships" [36-38]. This view is also shared by Anthony Giddens, who considers "institutionalized action" and "routinization" as foundational in the establishment of social order and the reproduction of social systems [39] (p. 2). Agents, by their practical activities, and structures (basically appearing as rules and resources), by their regulative effect, mutually enact social systems, which are reproduced over time through continued interaction. The SIMRA model of social innovation [9] is a practical application of this perspective (see Figure 1) for the purpose of evaluation; it puts the "reconfiguring" of social practices as the central mechanism of change.

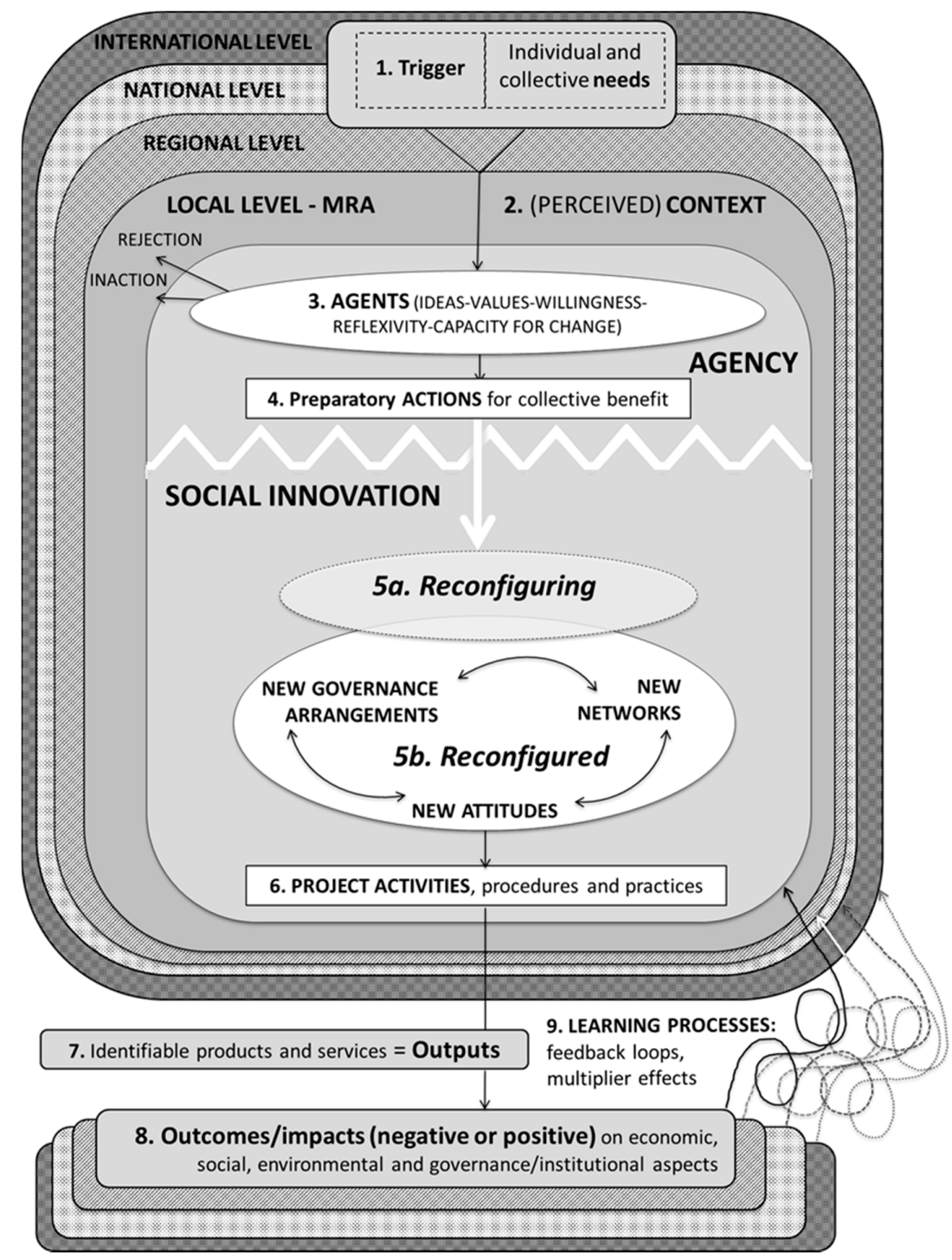

Figure 1. SIMRA evaluation framework proposed to evaluate social innovation and its impacts in marginalized rural areas (MRA) (source: adapted from Secco et al. 2017 [9] (p. 36)).

According to this model, the social innovation process occurs in phases: (1-2) the need for change is perceived by a group of people, maybe as an uneasiness that becomes manifest in the course of events that trigger agency (3-4), leading to reconfiguring social practices (5), eventually routinizing 
into reconfigured practices, which in turn result in new activities, outputs, outcomes, impacts, learning, and multiplier effects, albeit not always and at different scales (6-9) (Figure 1).

\subsection{Institutions, Trust and Governance}

Following Giddens' line of thinking, the "reconfiguration of social practices" results in "stable, valued, recurring patterns of behavior" called "institutions" [40,41]. Ostrom and Walker highlight the importance of reciprocity in the process of homogenization of behavior through learning how to build reputation for being trustworthy over a time frame that extends beyond the immediate present [42] (p. 40). Luhmann (1984) sees trust as a means to reduce complexity in social interactions [43], and Putnam (1993) considers "social capital" essentially as the available "amount of trust", comprising "features of social organizations, such as networks, norms and trust that facilitate action and cooperation for mutual benefit" [44] (p. 35).

Lasting changes in social practices imply the replacement or "creative destruction" of previous practices. Consequently, the dialectic between innovation and institutionalization means that the mere idea of a political framework that fosters innovation-nothing less than the (at least piecemeal) creative destruction of institutions-appears paradoxical [45] (p. 139). Considering social innovation and institutional change as indivisible, there has to be, in addition to renewal from bottom-up (social innovation), something like renewal from above (institutional innovation). This can be observed in an inclusive societal context where political reforms, strategies, and programs aim to promote self-organization, self-determination, and empowerment of less favored groups, thereby practicing "controlled loss of control" [46].

Consequently, the institutional fabric of a society is the realm in which policies and political frameworks (from top-down or from the outside to the inside) intertwine or collide with social innovation (from bottom-up or from the inside to the outside). Social innovation initiatives may either challenge the political-institutional fabric or act on invitation, bringing forth the pilot projects and practice examples-called "niches" in transition theory—that policy makers need to put forward and expand their agendas [47]. These patterns seem to be generalizable, notwithstanding the differences between political-institutional environments in different geo-political regions, manifesting themselves, among others, in the varying role of the state regarding social cohesion and the division of roles attributed to the public, private, and civil society sphere, as well in the level of trust [42] in modern-day institutions and modes of governance in particular.

\subsection{Public Governance and Social Innovation}

Governance is a synonym for steering functions and structures. It may entail the involvement of public, private, and civil society actors. We speak about public governance when we address the specific efforts public entities (from the EU and the state down to local self-governing bodies) undertake to accomplish public duties and improve common well-being. Hence, policies and political frameworks are part of public governance. Institutional change induced by social innovation manifests itself in changing patterns of governance, e.g., in the cooperative movement, in the health sector, in the financial sector, and in rural policies. However, the actual degree of involvement of public actors in fulfilling societal functions varies. Households, civil society organizations, and even local businesses can also be important providers of societal services.

While examining how social innovations and policies interact, we discover mutual relationships and interdependencies that vary across cases and change over time in relation to the evolution of policies and in relation to the stages of social innovations $[7,15]$. The main hindering and furthering influences from policies and political frameworks on social innovation have been analyzed by the SIMRA project but have already been mentioned in earlier works $[15,17,18,48,49]$. 


\subsubsection{Factors Hampering Social Innovation}

Any innovation or change challenges established routines, ways of thinking, and power structures and may therefore meet resistance from established actors when they perceive criticism or a threat of losing influence [50,51] (p. 13). Depending on the inclusiveness of the political-institutional environment $[52,53]$, and on the field of activity, the existing political frameworks and policies may actively welcome or suppress, or passively favor or hinder it. Hindering political frameworks may also entail specific regulations that fit to existing practices but ignore or do not allow other forms of delivery of products or services. Divisions between policy departments, sector policies, and silo thinking [18,54-56] limit the effectiveness of policies supporting social innovation. Sector silos emerge from a lack of openness and willingness towards risk-taking of public officials operating in clear-cut administrative hierarchies $[54,57]$. The coordination or integration of policy goals and political measures across departmental divisions has proven to be a major challenge [50], particularly for cross-sectoral policy goals such as innovation, sustainable development, or social innovation.

Social innovation initiatives and societal processes inevitably follow unpredictable pathways over the longer term $[8,58]$. Their trajectories include latent phases and loops of trial and error. The long-term character of social innovation is often disregarded by policy makers who tend to follow short-term political priorities and signals. Further, impacts may not become visible very fast, which makes impact evaluations difficult [59]. In effect, major institutional change may remain under the radar of the polity for some time: when changes gain ground over a longer period of time, they are not yet perceived as new or innovations. The absence of political goodwill is often paired with the lack of financial resources and access to relevant knowledge.

\subsubsection{Furthering Factors}

Appropriate institutional policies and political frameworks provide an enabling environment and create room for manoeuver for social innovators to generate and realize their ideas [4] (p.38). Support of this kind may be generic, such as constitutional provisions, legislation on co-operatives and non-profit associations, regulations on Environmental Impact Assessment, rural proofing, or on the delegation of powers to local communities. They may also be quite specific, particularly within the frameworks of federal constitutions, such as state regulations and supportive policies on decentralized and community-based energy provision [19] and other policy niches, such as communal land ownership and resource management [60], natural disaster prevention and management [61], and new forms of social care combined with agricultural diversification [62] — virtually any collective task taken over by local communities or groups of actors on the basis of formalized shared responsibilities.

To break vicious circles, improvements in the basic infrastructure as well as specific support activities for knowledge exchange, capacity building, participatory regional development, and social initiatives can wield considerable leverage. Investments into opportunity structures like physical and virtual education facilities, third sector employment opportunities, regional and local development hubs and agencies, IT connectivity, technology centers, business incubators, co-working spaces, and advisory and information services improve the milieu in which social innovation can emerge and grow. Community-based development bodies such as a local development association or trust provide a useful instrument to design and implement these needs-based investments [60] (p. 2).

Innovative solutions often emerge in response to cross-cutting problems, overcoming the blindness of established sectoral structures and routines. However, social innovation initiatives often originate in specific sectors and are therefore studied mostly from the sectoral point of view, but structural policies favoring cross-sectoral cooperation play a crucial role. Support of this kind comes from both national and European Cohesion Policy instruments. These include community-led programs for the support of civil engagement, the third sector, and social entrepreneurship, in particular, the EU CLLD/LEADER instrument for integrated rural and regional development. CLLD is an acronym for Community-Led Local Development, the generalized version of LEADER (acronym for "Liaison entre actions de développement de l'économie rurale"). In line with Dargan and Shucksmith [63] 
(p. 282), social innovation arguably "belongs to the core tasks of LEADER" [21] (p. 95), although the actual expression of the CLLD/LEADER approach in certain national and regional administrative contexts can be "hideously complicated", as Slee exemplified on the basis of LEADER implementation in Scotland/UK 2014-2020 [64].

Policies that offer participation opportunities for stakeholder and citizen engagement can foster social innovation by enabling and encouraging people to share their concerns and ideas and co-create solutions meeting the development needs of their communities. The participation of civil society groups and organizations is also a driving force in the reconfiguration of social practices $[61,65,66]$. This is also emphasized in the open innovation discourse, which sees human capital creation and knowledge diffusion as main levers to foster business innovation networks [14].

Policies fostering social innovations need to be flexible and embrace failure as an acceptable outcome. Ring-fenced and untagged seed money can have a big impact on the viability of social innovation projects, even with small amounts $[20,21]$. This acceptance and flexibility requires a broader understanding of social innovation, as compared to a merely technological-economic perspective.

\section{A Heuristic Model: The Triad of Actors}

The list of hindering and furthering factors that has been shortly recalled in the previous section appears, time and again, in relevant studies, and provides the substance for relevant policy recommendations. To make this list of policy recommendations more consistent and easier to grasp, we need a tool that highlights the main elements in their connectedness and mutual relationships. Such an instrument would enable innovation promoters, policy makers, and advisers to concentrate on the essentials and to provide situation-specific advice for action. After detailed analysis of numerous case studies from SIMRA and other sources, the authors decided to make a step in that direction.

As was already hypothesized in the analysis of policy impacts in the SIMRA project [14] (p. 96) we focus on three important groups of actors that have central roles and interrelations in the social innovation process. Their individual strength and the appropriate cooperation between those groups of actors appears to be a major determinant of the success of social innovations, which means that the resilience and dynamism of cooperation systems [67]—in which social innovators and policy makers come together to co-create something new-benefit from a concurrent "triad of actors" (Figure 2):

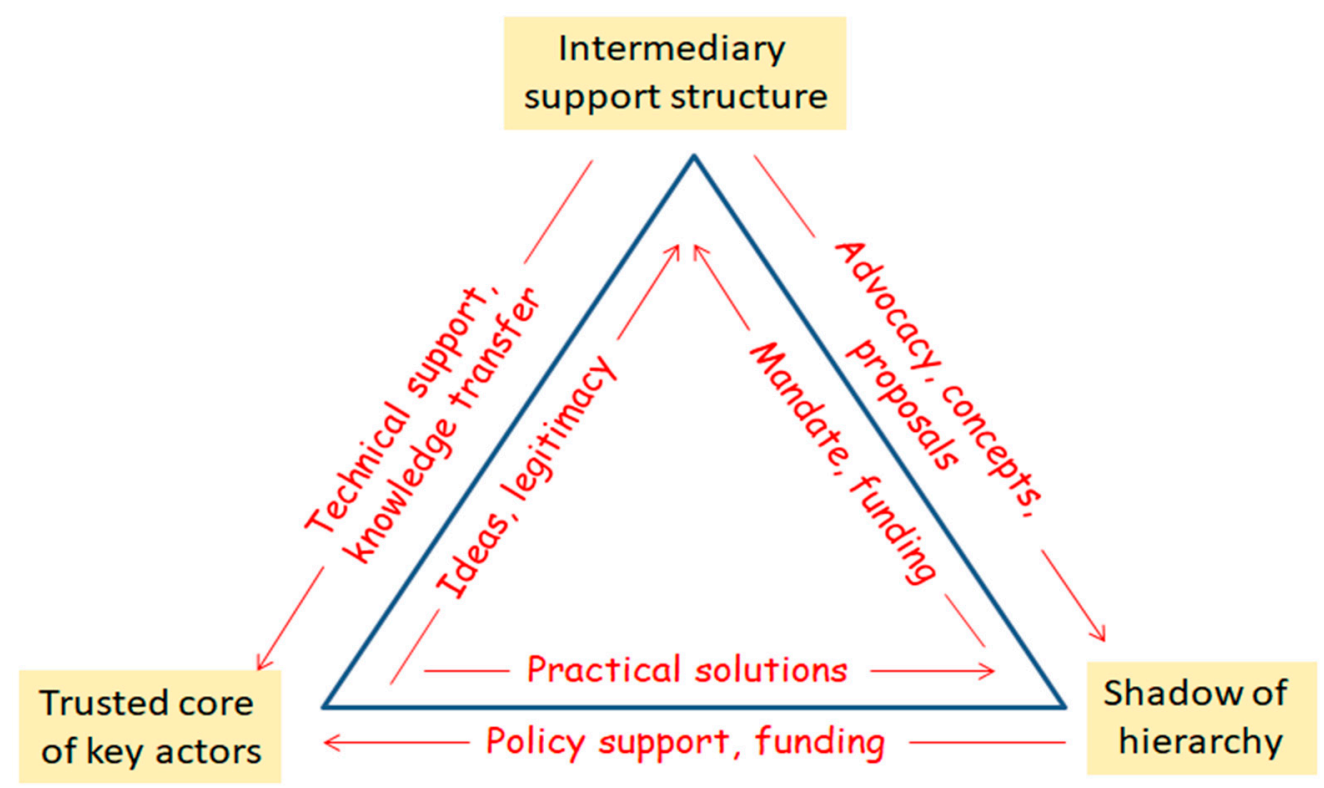

Figure 2. The triad of actors in social innovation (Source: Own design). 
(i) a trusted core of key actors;

(ii) an intermediary support structure;

(iii) public actors providing the shadow of hierarchy.

\subsection{A Trusted Core of Key Actors}

The most visible part of social innovation initiatives are their individual promoters. Apart from their capabilities and motivational strengths, much depends on the trust they have in each other and the degree to which they are trusted by the wider network of actors-especially of the community with which they work $[4,14]$ (p. 39, p. 41). Consequently, any evaluation framework for social innovation should include indicators on social capital [11,68].

\subsection{Intermediary Support Structures}

Referring to the binary interactions between the "top-down" and the "bottom-up", there needs to be a "third figure" [69], a "hinge", which stabilizes and at the same time dynamizes these interactions: this role is played by intermediary support structures embedded in the ambient institutional fabric. They are often highlighted as "third sector agencies or structures" $[24,70]$ that provide support to the social innovation initiatives in their remit, which may be defined in terms of thematic, functional, or territorial responsibilities. Such support may consist in acquisition and transfer of funding, trainings and other forms of knowledge provision, coaching and mentoring, networking, and lobbying. Some of these intermediary support structures aim to cover all these aspects [65], others are monofunctional, which requires that there may be more than one intermediary body working alongside in order to cover all relevant support needs. Social innovation initiatives on a growth path tend to spawn higher-level intermediary bodies, which serve both as protective shells towards the outside and as service providers supporting single initiatives [61]. They may serve as first responders [71] or deliver professional services to target groups. In the context of international cooperation, intermediary support structures are often hatched by donor-funded development projects [72]; in some cases, education, research, and training centers play a crucial role in facilitating dialogue and transferring knowledge. Intermediary support structures may take shape as dialogue platforms and event spaces gradually emerging from virtual communities and networks of like-minded supporters, institutionalizing over time [73]. Ludvig et al. [74] and Weiss et al. [75] analyze the important and complex roles of intermediary support organizations that may provide external support but can also be part of the innovations themselves. Existing organizations may grow into this role, but they may also emerge spontaneously, most likely in fields where "wicked problems" [76] persist, where neither market forces nor public intervention seem to provide acceptable solutions. In those complex problem situations, standard approaches for solutions are bound to fail [77], and intermediary structures provide capacities for developing new ways for problem solving. They may be initiated from the "bottom-up" as umbrella or lobbying organizations [61] or "top-down" as implementing bodies for state support structures in certain sectors, such as communal forest management [60], cultural innovation [78], or nature preservation [79]. Their specific characteristic as intermediary bodies lies in their linking and translating functions between the local initiatives and the polity. They inform in both directions on the basis of their knowledge of problem situations but also structures, rules, and values on both sides.

\subsection{The Shadow of Hierarchy}

The benevolent "shadow of hierarchy" [80] appears to be propitious for the emergence and growth of social innovation initiatives. This means that relevant public actors, at least tolerating if not actively encouraging social innovation initiatives, are important drivers of success. The shadow of hierarchy is two-edged: It involves a mixture of legislative inducements and sanctions, encouragement and control. In one way or another, the presence and active inclusion of public partners within or close to the social innovation initiative conveys the benediction of the society as a whole. Their involvement endows the initiative, but also intermediary support structures acting on behalf of several similar 
initiatives with the necessary legal backing, trust, and creditworthiness. In return, the public sector is relieved of certain tasks that seem to fare better when delegated to civil society actors or mixed partnerships. The degree of public influence may range from passive involvement in long-term contractual relationships to legally binding public-private-civic governance arrangements. Trust in institutions and trust among the people involved plays a crucial role for the social innovation to grow and thrive. Marini Govigli et al. [73] show the relevance of encouragement by the local polity, even in the absence of substantial institutional support. In his study on tailored polities in the framework of the European CLLD/LEADER rural development measure (2014-2020), Servillo [81] has shown how diverse program delivery can be in different political-institutional settings and due to previous experiences with the measure across European states and regions.

\section{A Closer Look on Three Social Innovation Initiatives}

\subsection{Apprentice Worlds, Promoted by the Local Action Group "Zeitkultur Oststeirisches Kernland" in Styria, Austria}

The promoter of the initiative is the LEADER Local Action Group named Zeitkultur Oststeirisches Kernland. The LAG operates in an economically lagging rural area with attractive landscapes shaped by small farms, villages, and towns, and a well-founded tradition in a broad range of crafts, from construction to creative and culinary businesses. The social innovation we speak about here emerges from a string of projects titled Creative Apprentice Worlds, which the LAG initiated and implemented on its own account from 2012. The main mission of Apprentice Worlds is to contribute to solving a most pressing problem, the shortage of apprentices and skilled labor in all Styrian regions and economic sectors [22].

Apprentice Worlds are based on the concept of so-called "work boxes" originating in a building trade initiative called Werkraum (Factory Space) Vorarlberg dating back to the turn of the century, which had also benefitted from LEADER at that time. With the help of one of the Werkraum architects, the LAG developed the original, more illustrative, and therefore static concept of work boxes further into interactive and mobile ones, under the assiduous and not always easily manageable participation of local entrepreneurs, vocational trainers, and students/apprentices. A work box can be described as a wooden cubicle, containing modular elements, which, once unpacked and unfurled, not only illustrate the main features of a particular craft (from hairdresser to carpenter, cook to pastry baker, including crafts falsely stigmatized as without hope of success, such as book printers). The workboxes also serve as workbenches on which small artefacts can be crafted. To date, 25 work boxes have been designed, built and utilized during practical job orientation events in secondary and primary schools around the State of Styria. In these events, pupils and students work on the workbenches, supported by local entrepreneurs who participate voluntarily and benefit from the enhanced probability that one or the other student would one day sign in as their apprentice after leaving school.

The workboxes are transportable and shipped for free to the schools hosting the job orientation event, mostly for one full day in their sports halls. Starting in 2014, the Work Box Road Shows have already reached more than 100 schools and involved more than 6000 students and pupils in Styria, let alone the many local entrepreneurs who contributed to these exciting events, which resemble a big party rather than an ordinary day in school.

The social innovation initiative stretches over ten single projects, which were artfully engineered by the LAG and project management staff. Two projects were carried out in the framework of transnational cooperation; one funded from the Territorial Cooperation Fund (called INTERREG, being a part of the European Regional Development Fund) together with Hungary and another one from the LEADER transnational cooperation sub-measure of the European Agricultural Fund for Rural Development. Stakeholders from other Austrian regions, Luxemburg, Germany, and Italy have shown interest in methodological transfer.

Triggered by the arrival of many refugees via the Balkan route in the year 2015, the LAG combined the job orientation concept with integration measures in a project called Future-oriented Apprentice Worlds, 
whose main beneficiaries were supposed to be juvenile asylum seekers. The Austrian government found this approach commendable and even awarded it an innovation prize. After the 2017 elections, the newly formed government banned asylum seekers from apprentice jobs and the concomitant vocational training as long as their asylum status was not confirmed, which meant an indefinite time of idleness and uncertainty for young people who eagerly wanted to learn and integrate themselves into the society. This was the apparent death knell for the Future-oriented Apprentice Worlds, but the LAG, in collaboration with a regional non-profit organization working in the social care sector, managed to redraft the operational plan through shifting the focus to the long-term unemployed youth.

The weak point of the social innovation initiative Apprentice Worlds may lie in the uncertain mainstreaming transition. Although the approach has been praised by all relevant stakeholders (e.g., the Chamber of Commerce, many entrepreneurs, and the State government), and although the resonance and demand from schools remains unabated, it seems to be difficult to insert the innovation into the prevailing job orientation practices and structures. Neither the Chamber of Commerce, nor vocational training schools, nor labor market services take the lead and latch onto this initiative. It appears that the branding of the initiative by the LAG has caused some reticence among stakeholder groups against stepping in as a vehicle for institutional insertion and mainstreaming.

What lessons can be drawn in terms of policy implications from this social innovation initiative?

- The initiative emerged at the interface between specific policy fields, in this case education and labor market policies. It literally straddles these two, with remarkable implications on a wider spectrum of policies regarding youth, social inclusion, and the regional economy marked by tradition-rich craft businesses. Inconsistencies and gaps in the institutional fabric at the fringes of policy fields have helped trigger the initiative, but these gaps continue to pose problems when it comes to the question of scaling up and mainstreaming.

- The creative use of diverse funding options from structural (LEADER and INTERREG) and sectoral funding sources (from the State government education department), orchestrated in an uninterrupted row of projects over eight years, would not have been possible without the visionary force and negotiating power of the Local Action Group and its management, based on the independent mandate from bottom-up.

- The LEADER approach allows for a double role of the local partnership: first as a financial enabler and supporter of social innovation, and second as a promoter and spearhead of social innovation. The LAG in its dual role as an innovative core actor and as a prototypical intermediary support structure has spawned this social innovation initiative, but still not achieved the stage of cord clamping the former from the latter. Thus, the LAG is more and more perceived as a main actor in the respective policy fields, to the detriment of its position as a cross-sectoral, cross-thematic, and impartial enabler, which makes it vulnerable to getting tied up with the ups and downs of local politics and jealousies between different stakeholder groups. However, the original intention of the LAG was not to become a major actor in this field. It would rather like to hand over the activities to incumbent operators, but the historically grown delimitation of competences seems to hamper the integration of the reconfigured practice.

- The case provides a vivid example of how institutional frameworks can have both reinforcing and debilitating effects concurrently. On the one hand, the combination of the hands-on approach to job orientation with the integration of asylum seekers was singled out as being exemplary in a nation-wide competition by the national government; on the other hand, the same initiative got shattered by the work ban for asylum seekers, which was put in place by the ensuing government. The result of antithetic political tendencies was not neutrality, but blockade.

- $\quad$ Figure 3 provides some salient features of the triad of actors appearing in the Styrian case example. These are also described in Table 2 in the discussion section where the three cases are compared. The LAG has succeeded in spawning an initiative that meets an urgent societal need that has not been properly met by existing institutional arrangements. What has not been achieved so far is an impact on the institutional frameworks in a way that guarantees the insertion of 
the innovation without any longer depending on the LAG, which, as an intermediary support structure, understands its role as social entrepreneur to generate local innovation rather than to become a permanent service provider in a specific sector or thematic field.

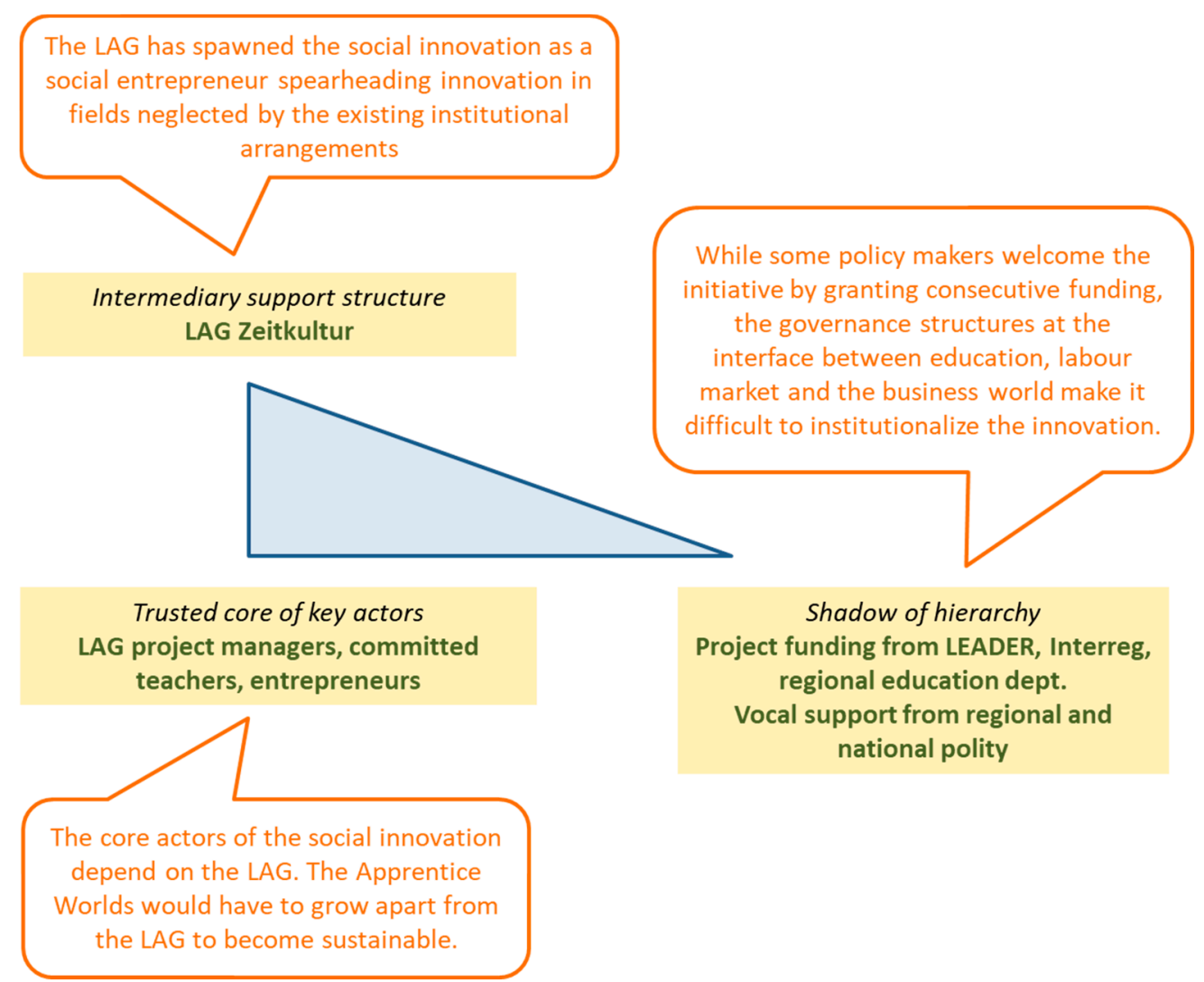

Figure 3. The triad of actors in the Apprentice Worlds (Source: Own design). 
Table 2. Lessons from the analyzed cases (Synthesis).

\begin{tabular}{|c|c|c|c|c|}
\hline \multirow{2}{*}{ Triad Elements } & & \multicolumn{3}{|c|}{ Triad Features } \\
\hline & & $\begin{array}{c}\text { Austria } \\
\text { (Apprentice Worlds) }\end{array}$ & $\begin{array}{c}\text { UK/Scotland } \\
\text { (Braemar Community Trust and Hydro) }\end{array}$ & $\begin{array}{c}\text { Serbia } \\
\text { (Fenomena Association) }\end{array}$ \\
\hline \multirow[t]{3}{*}{ The nodes } & Trusted core of key actors & $\begin{array}{l}\text { Strong: Enduring management } \\
\text { of more than ten different } \\
\text { projects under the strategic } \\
\text { guidance of the LAG } \\
\text { management. Different projects } \\
\text { have been seamlessly } \\
\text { customized to promote the } \\
\text { initiative. }\end{array}$ & $\begin{array}{l}\text { Strong: Braemar Community Limited with } \\
\text { Braemar Community Hydro as the } \\
\text { economic mainstay. Broad, locally } \\
\text { anchored ownership with a high } \\
\text { potential for internal diversification. }\end{array}$ & $\begin{array}{l}\text { Strong: Persevering dedication } \\
\text { and social commitment of core } \\
\text { actors. }\end{array}$ \\
\hline & Intermediary support structure & $\begin{array}{l}\text { Strong: Over the years, } \\
\text { Apprentice Worlds have been a } \\
\text { flagship initiative of the LAG } \\
\text { with strong backing by the } \\
\text { chairman and active leadership } \\
\text { by the LAG manager. The LAG } \\
\text { not only provided the } \\
\text { appropriate structure for } \\
\text { funding, but also knowledge } \\
\text { transfer and regional, national, } \\
\text { and European networking. }\end{array}$ & $\begin{array}{l}\text { Strong and two-pronged: The Scottish } \\
\text { Development Trusts Association } \\
\text { represents the interests of a large number } \\
\text { of similar initiatives at the national scale } \\
\text { of decision making, whereas top-down } \\
\text { support is effectively delivered by } \\
\text { sectoral state agencies. }\end{array}$ & $\begin{array}{l}\text { Intermittent and delicate in } \\
\text { terms of political contingencies: } \\
\text { Full reliance on international } \\
\text { donors and development } \\
\text { projects. }\end{array}$ \\
\hline & Shadow of hierarchy & $\begin{array}{l}\text { Obtainable, but dispersed: } \\
\text { There is widespread recognition } \\
\text { among the regional and national } \\
\text { polity, but not sufficient political } \\
\text { will to institutionalize the } \\
\text { initiative due to the } \\
\text { perseverance of sectoral } \\
\text { divisions and role attributions. }\end{array}$ & $\begin{array}{l}\text { Strong, but still improvable: The } \\
\text { constitution of the nation state provides } \\
\text { the matrix for a broad political consensus } \\
\text { on community empowerment. Some } \\
\text { friction losses through sectoral silos and a } \\
\text { weak territorial cross-sectoral } \\
\text { coordination (LEADER) dominated by } \\
\text { municipal interests. }\end{array}$ & $\begin{array}{l}\text { Weak: Encouragement by an } \\
\text { internationally funded unit at } \\
\text { the Prime Minister's office. }\end{array}$ \\
\hline
\end{tabular}


Table 2. Cont

\begin{tabular}{|c|c|c|c|c|}
\hline \multirow{2}{*}{ Triad Elements } & & \multicolumn{3}{|c|}{ Triad Features } \\
\hline & & $\begin{array}{c}\text { Austria } \\
\text { (Apprentice Worlds) }\end{array}$ & $\begin{array}{c}\text { UK/Scotland } \\
\text { (Braemar Community Trust and Hydro) }\end{array}$ & $\begin{array}{c}\text { Serbia } \\
\text { (Fenomena Association) }\end{array}$ \\
\hline \multirow[t]{3}{*}{ Edges linking the nodes } & Core actors $<->$ support structure & $\begin{array}{l}\text { The key actors (Apprentice } \\
\text { Worlds) still fully depend on the } \\
\text { intermediary support structure } \\
\text { (LAG Zeitkultur). Independent } \\
\text { ownership would be necessary } \\
\text { to make the initiative } \\
\text { sustainable. }\end{array}$ & $\begin{array}{l}\text { Strong ties: Technical top-down support } \\
\text { complemented by bottom-up } \\
\text { representation of interests. }\end{array}$ & $\begin{array}{l}\text { Strong ties based on } \\
\text { longstanding experience in } \\
\text { international fund raising and } \\
\text { project acquisition, but overall } \\
\text { dependency on project cycles. }\end{array}$ \\
\hline & $\begin{array}{l}\text { Support structure }<->\text { shadow of } \\
\text { hierarchy }\end{array}$ & $\begin{array}{l}\text { It has cost the LAG some time to } \\
\text { become acknowledged as a } \\
\text { social entrepreneur in this field, } \\
\text { but it has succeeded in it. This } \\
\text { has, however, not led to regime } \\
\text { change, which would allow the } \\
\text { Apprentice Worlds to get } \\
\text { mainstreamed. }\end{array}$ & $\begin{array}{l}\text { Strong and consistent: The structures are } \\
\text { built upon the consensus on } \\
\text { decentralization and community } \\
\text { empowerment. Sector silos and } \\
\text { municipal power claims constitute } \\
\text { challenges. }\end{array}$ & $\begin{array}{l}\text { Strong link between the two } \\
\text { nodes through international } \\
\text { donors, with only weak } \\
\text { embedding in the Serbian } \\
\text { domestic policy context. }\end{array}$ \\
\hline & $\begin{array}{l}\text { Shadow of hierarchy }<->\text { core } \\
\text { actors }\end{array}$ & $\begin{array}{l}\text { There is an ongoing dialogue } \\
\text { between project promoters and } \\
\text { local and regional polity, } \\
\text { fostered by the LAG, which, as a } \\
\text { well-established public-private } \\
\text { partnership, provides the } \\
\text { institutional space for } \\
\text { continuous concertation across } \\
\text { all sectors. }\end{array}$ & $\begin{array}{l}\text { The local initiative, like many similar } \\
\text { ones in Scotland, responded to an open } \\
\text { invitation, which was based on the } \\
\text { political consensus on decentralization } \\
\text { and community empowerment. }\end{array}$ & $\begin{array}{l}\text { There is no political provision } \\
\text { (funding, advice) for social } \\
\text { innovation support, and core } \\
\text { actors operate under conditions } \\
\text { of permanent uncertainty in an } \\
\text { overall unstable } \\
\text { political-institutional } \\
\text { environment. }\end{array}$ \\
\hline
\end{tabular}


Table 2. Cont

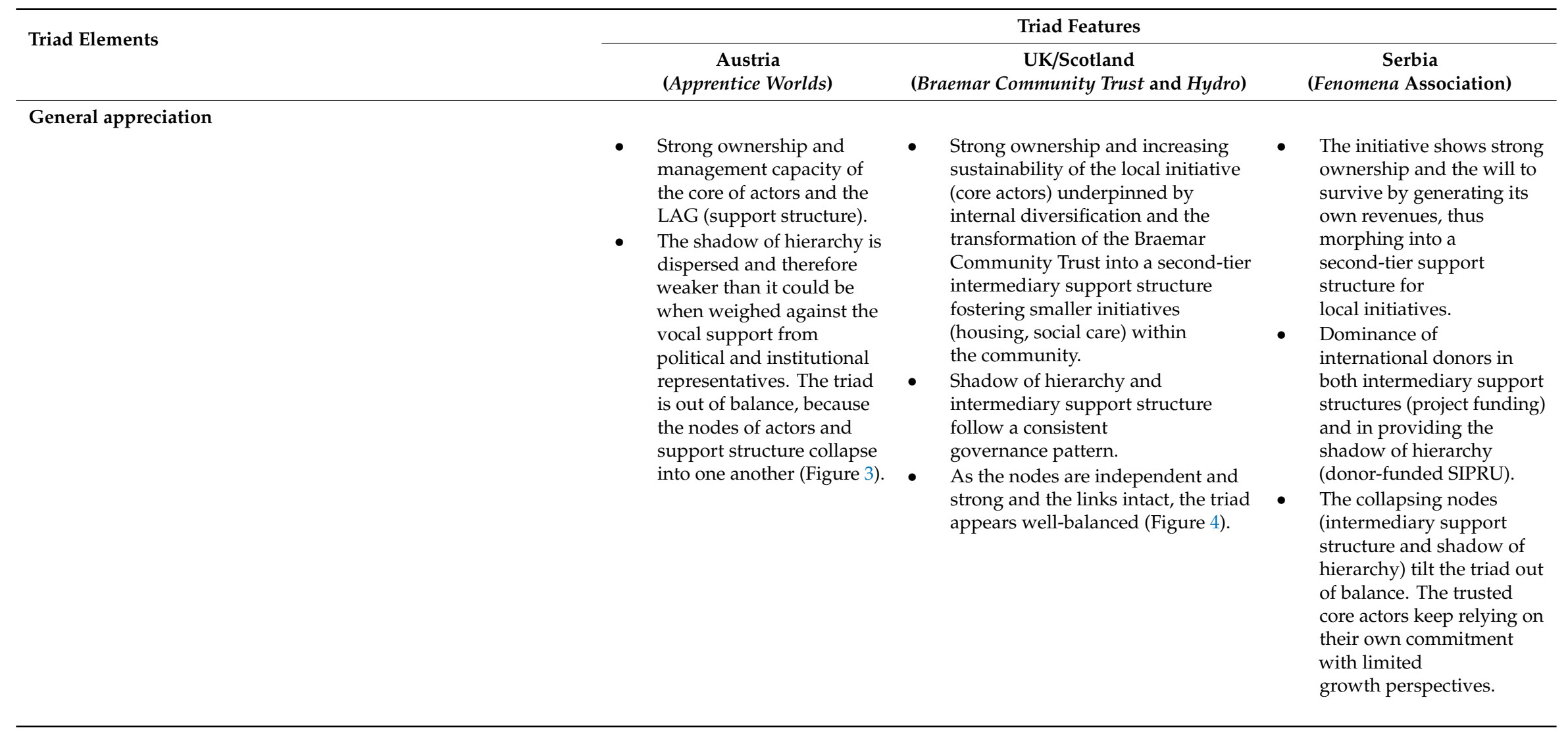




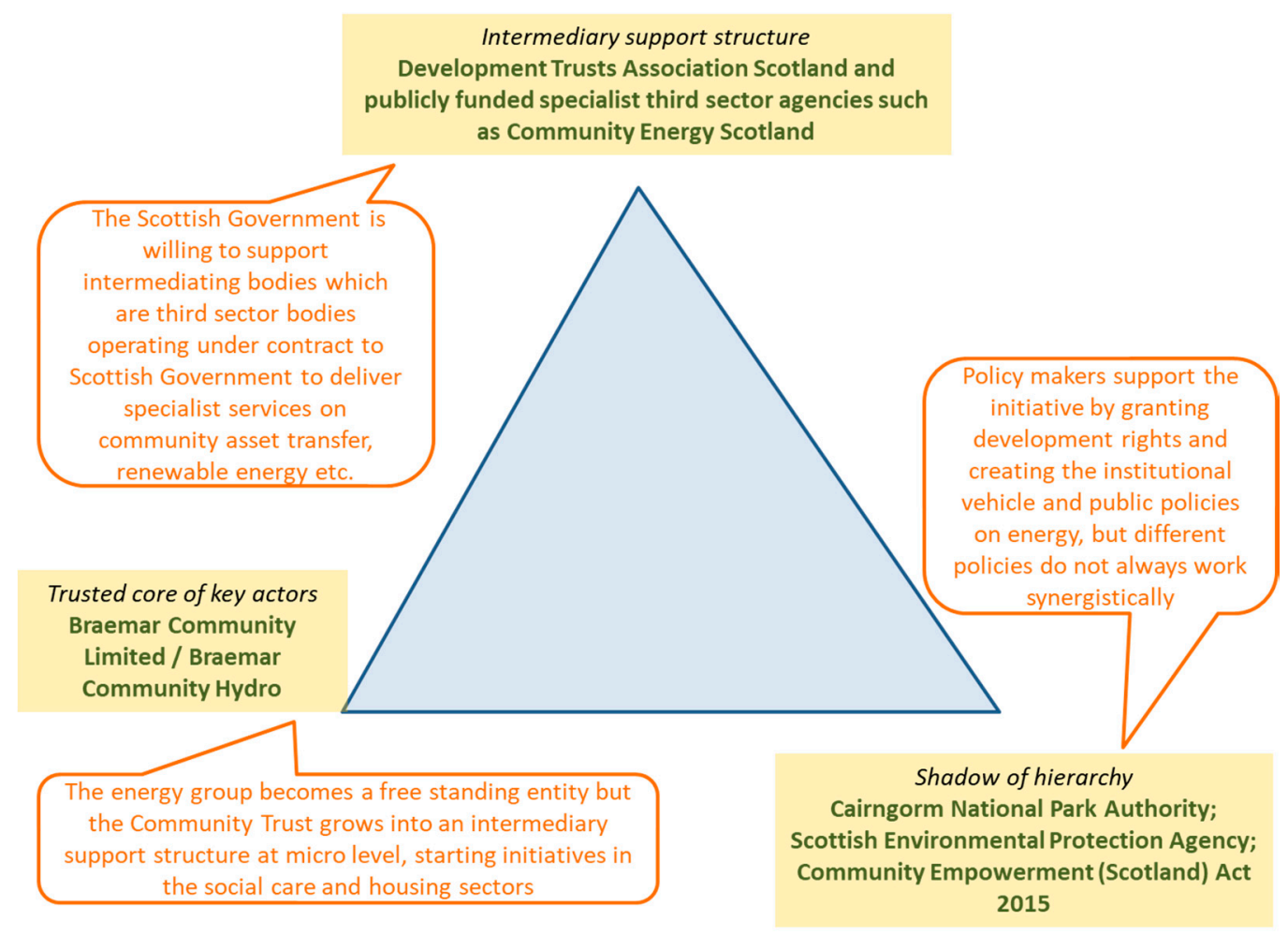

Figure 4. The triad of actors in Braemar Community Hydro (Source: Own design).

\subsection{Braemar Community Hydro in Scotland/UK}

Over the last decade the mountain village of Braemar in the center of the Cairngorms National Park has been the setting for a number of social innovations [24]. The driving force of innovation has come from a Community Development Trust, which comprises a legal entity that aims to help their neighborhoods flourish through community-led activity, partnership working and enterprise. It was established in Braemar in 2004 by the community of around 400 people, just after the designation of the national park, and was self-consciously promoted by its early leaders as an agency to bring decision making relating to local development back into the community in order "to pursue opportunities for economic growth through the sensitive development of the natural environment" (Article 3e of its charitable incorporation document), to improve local services, and to consider community heating. Since its establishment, it has been responsible for a number of significant projects relating to the built heritage, promoted a community hydro-power scheme, and had a major role in initiating a social enterprise dealing with domiciliary social care for local people.

Although Braemar Community Hydro is now a free-standing community benefit society-essentially a cooperative entity that exists not only to support its members but also with a financial commitment to a place-based community in which it is located-its origins lie in the strategic thinking of the Community Development Trust. It had promoted the idea of developing a former private hydro-power plant that had existed to supply a large landowner with electricity prior to the establishment of a publicly owned electricity grid in Scotland in the period after the Second World War. The primary rationale for re-developing the hydropower site as a community-owned enterprise was to provide a revenue stream for the recently established Community Development Trust. The re-development of the site required extensive engagement with engineering consultants, regulatory authorities, including the national park and the Scottish Environmental Protection Agency, the landowner of the site, as well as active participation of a core group of unpaid local citizens. Semi-public agencies such as Community Energy Scotland also provided support as the project developed. The development group, which had received funding from the development trust to support their project development efforts, decided to 
use the community benefit society as the legal entity to support the development. This was seen as necessary because of the economic marginality of the project, the high cost of achieving due diligence with commercial lenders, and the relatively high interest costs they would be confronted by.

There were numerous obstacles that this pioneering community energy development encountered. These included the high costs of due diligence on any commercial loans, the self-interested behavior of the landowner, and the unreliability of an engineering consultant's report. Without a strong repository of human capital from retired engineering professionals and what one board member described as "sheer bloody-minded persistence", this development could easily have foundered. Those currently running the project noted in a focus group how this kind of cooperative local venture would have been inconceivable twenty years previously. Third sector agencies had emerged as a viable institutional form in the renewable energy field, but also more widely through other activities of the Community Development Trust.

The project was completed in 2017 at a time when high levels of public support for renewable energy through feed-in-tariffs guaranteed support over a 20-year period. To date, there have been two disbursements of support to a wide range of community groups in Braemar who bid for funding to a panel comprising Braemar Community Hydro and local community representatives, and in addition, investors have received a steady return on their investment. As the investors are paid back, so the amount available for community benefit rather than private reward will increase.

The success of this project raises some questions. How could such a project emerge and succeed, despite encountering a number of crisis points as it evolved? First, there had been a culture shift towards recognizing that place-making in remote rural Scotland required collaborative effort and third sector involvement rather than merely patriarchal landownership and/or public agency. Braemar had already begun to develop strong social capital, which to a degree replaced the paternalistic power of the large landed estates with a new order of lifestyle migrants and early retired professionals, who had strong bridging capital and whose collaboration was vital to the project's success. Second, two types of policy change had enabled the development. Firstly, legislation had created the possibility of community benefit societies, which were selected as the appropriate institutional vehicle for the project. Secondly, in a rapidly evolving energy policy arena, decarbonization imperatives were leading to significant incentives for small scale renewables projects, and the Scottish Government was supporting an arm's length agency that gave advice and financial support to community projects.

Since this project, Braemar has developed a social care initiative to deal with domiciliary social care of elderly residents, which is based in the community and comprises a social enterprise. It too was established, initially in conflict with established systems of provision, with support of the development trust and has become a free-standing third sector entity. Currently, the Community Trust is involved in developing social housing through yet another third sector agency, as house prices have risen beyond the reach of lower paid rural workers.

The co-existence of so many third sector agencies contributing to economic and social life in a small community reflects the extent to which public sector austerity has weakened public provision, but it also reflects the communitarian turn in Scottish policy making, which has empowered communities through generic legislation such as the Community Empowerment (Scotland) Act 2015 and sector-specific support for community energy through agency support and specific financing schemes. Whether Braemar's capacity can be replicated elsewhere is questionable. The high levels of bonding, bridging, and linking capital have almost certainly created opportunities for Braemar that are not available everywhere, but without an enabling architecture of Scottish rather than European policy, little could have been achieved.

Which lessons in terms of policy implications can be drawn from this social innovation initiative?

- An enabling policy environment is essential in community energy policy, in renewable energy commitments, and in supporting development trusts. The policy is only partially enabling. It still demands a huge community effort to bid into the public and third sector funds that support community-based development. 
- Strong social capital in the community and the willingness to engage with policy and a capacity to surmount difficulties are key. The case shows the importance of highly motivated and capable incomers combined with locals to produce solidarity and a capacity to act. Many communities lack these skills, and therefore the social innovation may well not be replicated everywhere.

- A set of challenges to the long-term viability of the community existed that demanded a local rather than a generic public sector response. The existing architecture of housing policy and of social care policy was not working. In the case of the energy project, this was opportunistic engagement, based on a desire to finance community development, breaking the reliance on funds from LEADER or the municipality.

- Figure 4 characterizes the triad of actors for the Scottish case example, and further explanations are included in the comparative Table 2. The Community Trust has come into being and thrives in response to receding public agency, in areas of community interests where individualist approaches provide even less answers. This development is certainly favored by the Scottish constitution and the public provision of intermediary support structures in various sectoral and thematic areas. This publicly driven effort is not always successful, as the rather bureaucratic handling of LEADER shows. However, the burgeoning of similar community initiatives all over Scotland led to the formation of an Association of Community Trusts (DTAS 2020), which enables the single community trusts to bundle forces and to get involved at national level of scale. Further down toward the micro level, the Scottish example shows the fractalness of the triad model, as the Braemar Community Trust is increasingly growing into the role of an intermediary support structure for local initiatives, which are supposed to run independently to the benefit of the people of Braemar.

\subsection{Agricultural Development Fund Fenomena in Serbia}

The Development Agriculture Fund Fenomena (DAFF) has been established by the Citizens Association Fenomena and operates as a business angel in support of integrated, sustainable agriculture in Serbia. The Fenomena Association works in the municipality of Kraljevo in central Serbia, where $45 \%$ of people live in rural areas. Agricultural production and processing have a high potential to support local economic development, as there are favorable environmental conditions and a significant proportion of the area comprises agricultural land (47\%).

In 2006, Fenomena started by getting involved in the topics of gender equality, the issue of domestic violence, and the position of women in society. Their work is centered around three initiatives: (i) a center for nonviolence-combating domestic violence and running an SOS phone-which has already operated for ten years; (ii) gender mainstreaming-advocacy for gender equality in public policies at national and local level; and (iii) social entrepreneurship, which started in 2011, as a way to achieve economic independence, because until that point the association worked on a project basis. As part of its social entrepreneurship focus, in 2015 Fenomena initiated DAFF, a fund that operates as an independent business angel providing capital for the development of small rural business promoters. The fund is the first of this kind in Serbia.

Fenomena acquired an initial budget of USD 30.000 from the Rockefeller Brothers Fund, which allowed the starting, piloting, and testing of the DAFF idea. The DAFF fund is strongly socially oriented and is used to invest in agricultural start-ups, benefitting young people or smallholders in the region who usually do not qualify for state subsidies, but want to stay in the village, create, and/or expand their businesses. Thus, DAFF supports local development. The principle is that Fenomena concludes loan contracts with micro and small agricultural producers or households on the basis of a business idea. The beneficiary is obliged to return the sum to the DAFF increased by interests ranging from 2.5 or $10 \%$, depending on the type of business and the expected benefits, from which the next business ideas will be financed. The duration of contracts depends on the business idea and the amount of money invested. The smallest contracts are for one year-amounts of about 600 to 650 EUR, for example, for an organic certificate and the purchase of some raw materials. The largest loans have a 
payback time of five years with sums of about 10,000 EUR. It is foreseen that part of the DAFF earnings (3-4\%) are invested into other activities of Fenomena, i.e., the SOS phone and support to the victims of domestic violence. Still, they cannot fully cross-finance these activities. At the moment, the main aim is to keep DAFF functioning and to gradually increase the volume of funding.

Since its early years, Fenomena got support from the Social Inclusion and Poverty Reduction Unit (SIPRU) formed by the Serbian government in 2009 and operating within the Office of the Prime Minister since 2018. The mandate of SIPRU is to strengthen government capacities to develop and implement social inclusion policies based on good practices in Europe. However, this body is financed by the Swiss Confederation as international donor only for a limited time. One of the major successes of the SIPRU team was to mobilize direct financial support to social enterprises through the EU IPA (Instrument for Pre-Accession Assistance) 2013 program [26]. Fenomena was one of the rare rural social enterprises to be financed through this instrument, namely, to create a curriculum for a training program for hard-to-employ groups of young people that aimed to start agricultural businesses. Its beneficiaries include young people without parental care, social allowance recipients, young women, and youth of Roma and other minority communities. The training curriculum was developed using existing practice examples from the DAFF fund. The IPA-funded action actually served to promote the DAFF and to attract more users. For the training purposes, Fenomena cooperates with the Regional Development Agency (RDA) Zlatibor, which now co-manages the training program and provides certificates for business plan writing, issued by the umbrella organization Regional Development Agency Serbia. This provides additional motivation for the beneficiaries to join the trainings.

Fenomena also conducted trainings in cooperation with other Serbian municipalities (Arilje, Užice), supporting the most promising participants with DAFF funding. Further cooperation has included other Serbian NGOs, like the Slow Food Network or SOS Children Villages. More recently, Fenomena acquired support from the German and Swiss International Cooperation (GIZ and SDC) and UN Women.

Fenomena operates under the Law on Association, which allows economic activities in order to provide additional resources necessary for carrying out their basic non-profit activities. According to the representative of the Fenomena Association, there are no specific policies supporting social innovations or enterprises in Serbia. DAFF was refused support from the funds of Ministry of Agriculture. This underlines the rather weak role that public actors take in supporting social innovations. The Fenomena representative stressed the need for supporting policies and financial instruments, especially for locally run social innovations, but also better cross-sectoral policies to foster innovative and organic agricultural practices. This would reduce dependence on international programs and donors. Moreover, the concept of social entrepreneurship and innovation is very narrowly understood in Serbia, as a means to employ vulnerable groups such as people with mental or physical disorders or handicaps. There is no common understanding that activities in agriculture can be innovative and socially oriented businesses. Many of the DAFF activities are unpaid and carried out on a voluntary basis by association members, which poses a sustainability challenge.

What lessons in terms of policy implications can be drawn from this social innovation initiative?

- This case shows that there is a high interest from civil society to become active in social issues and to contribute to solving local problems, experimenting new activities and new modes of cooperation with the local population, thus filling the gaps that now exist in the institutional system. However, the weak institutional environment barely provides appropriate political support for social innovation initiatives or enterprises. There is a need for specific policies and programs in recognition of social innovation as a broad concept spanning across and relevant to different sectors.

- The absence of specific supportive policies entails pronounced financial dependencies. Fenomena got support from international funds and is currently grappling with the challenge to secure further funding and to broaden its financial base. There is a need to diversify financial resources for social innovation, with public funds playing a key role in it. 
- The triad of actors in the Serbian case example is illustrated in Figure 5 and summarized in Table 2 . The weakest part of the triad is the shadow of hierarchy. There is no option for Fenomena to get funded from rural development budgets, but it has access to some funds for social activities from the government unit SIPRU directly attached to the Prime Minister's office. However, this office lives on support from international donors. For the sake of sustainability, the Association Fenomena created DAFF, a micro-finance instrument by which it supports activities of vulnerable groups in rural areas. As in the Scottish case, the fractalness of the triad model reveals itself to the extent as Fenomena becomes an intermediary support structure for local initiatives.

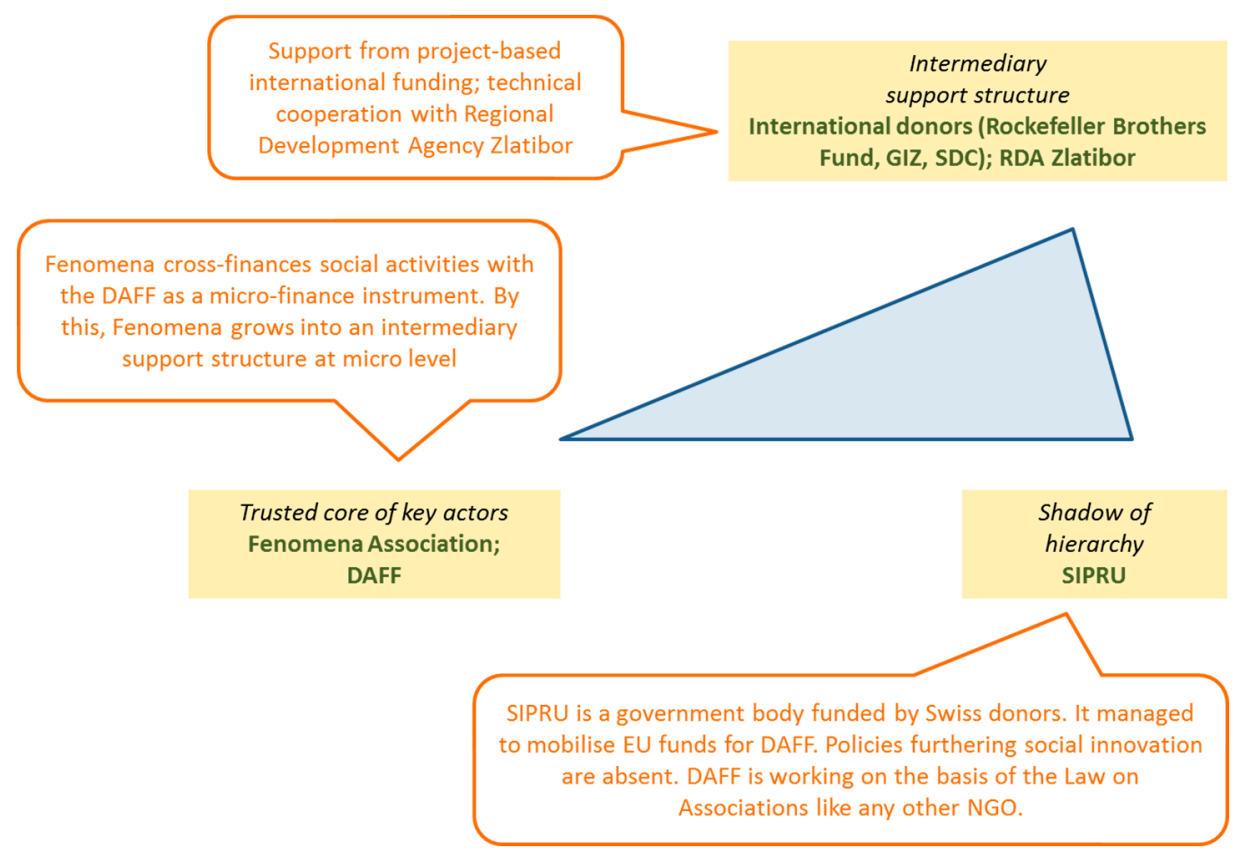

Figure 5. The triad of actors with regard to DAFF (Source: Own design).

\section{Discussion}

In this section, we bring together our insights from the case study analyses on the core elements (the nodes) of the heuristic model and the relations between the three actor groups (Table 2). On this basis, we discuss further detailed observations about, for instance, the implications of more or less balanced triads and development paths over time and how far recommendations for a better political support of social innovation can be derived.

\subsection{The Benevolent Shadow of Hierarchy}

The three cases illustrate the multifarious capacity of the benevolent hand of public policy-the shadow of hierarchy - in supporting social innovation to address persistent problems of socio-economic decline. In both the Austrian and the Serbian cases, new forms of support were established to nurture small businesses in rural villages and towns. In the Serbian example, the national government passively encouraged the activities of the DAFF through a donor-funded governmental entity (SIPRU). Institutional policies, basically the Law on Association, provided the backdrop for civil society activity. The political frameworks leave some options to citizens' initiatives as to how they can legally organize themselves if they want to pursue socially innovative activities. However, it does not have concrete specific policies or programs to foster social innovations as such. In the Austrian case, structural policies have had much better effects on the social innovation initiative than sectoral governance arrangements, which rather appeared as impediments to flexible handling. The Local Action Group was instrumental in generating the innovative action, striving to acquire an uninterrupted funding stream from various European (LEADER, INTERREG) and State-based support schemes. The situation in Scotland was 
different. Apart from the institutional policy background, which strongly encourages community-based enterprise, the Community Trust (Braemar Community Limited) was much better served by specific sectoral support schemes and structures (e.g., the Scottish agency supporting Community Energy, the National Park Authority, etc.) than by territorially defined policies (e.g., LEADER), with the municipality in a rather unsupportive role.

\subsection{The Importance of Intermediary Structures}

The types of organizations that take over the role of intermediary support structures are quite different in the three case studies, with the distant SIPRU as a donor-sponsored government entity in Serbia, whereas the Austrian LAG as a formalized partnership has the explicit mandate to instigate area-based innovative actions using a multi-sectoral, participative, and inclusive approach. The Development Trusts Association for Scotland purposefully connects top-down and bottom-up in a "down-up" structure [82], benefitting from an overall political-institutional environment in which local initiatives can expect policy support [75].

\subsection{The Trusted Core of Key Actors}

In all three cases, we see the indispensable role of civic action as a key driver, not only in generating the social innovation, but also in all consecutive phases, through carrying it through difficult times, to growing, and eventually scaling up and out. Whether long-term viability is sought through proper economic revenues (as in the Scottish case and also on a much smaller scale in the Serbian case), or through new institutional arrangements in the relevant field (in the Austrian case), there needs to be not only continued dedication in the heart of the initiative as such, but also the capacity to build trust and motivate key actors of the other two nodes, the intermediary support structures and the shadow of hierarchy, at best leading to the formation of a personal network that inspirits the reconfigured fabric of institutional actors from within.

\subsection{Bottom-Up and Top-Down}

The relationship between public policy and social innovation is shaped by two momentums. The first comes from top-down, when policy makers identify and frame a problem area and design supportive policies including the promotion of social innovation as a means to deliver desired outcomes. The minimum variant of this happens when public actors, plagued by political "hot potatoes" or wicked problems, slough off responsibilities to third sector institutions or donor-funded projects and let them work with public benediction at best or passive tolerance at least. The second momentum occurs when social innovation initiatives emerge in defiance of hindering or denialist policies and political frameworks and become so successful that the state finally endorses them and eventually designs policies to support new adopters. The degree of political encouragement has an impact on the presumed sustainability of the initiative, which seems to be weakest in the Serbian and strongest in the Scottish case. The Austrian case is peculiar in the sense that the social innovation is well received and praised by all relevant stakeholders, who at the same time act somewhat reluctantly when it comes to inserting the innovation into the existing institutional fabric.

\subsection{The Path Toward Long-Term Viability}

As for the viability of the described initiatives, the Austrian Apprentice Worlds are still resting on the shoulders of the LAG, the Scottish Braemar Hydro guarantees a constant stream of revenues for the independent community benefit society, while in Serbia, the revolving micro finance fund called DAFF still grapples with covering the running cost, let alone with cross-financing the social and gender-related solidarity work of the association. Both use the earnings to broaden and diversify the spectrum of activities and to nurture innovation on the ground, which, again in both cases, leads to a replication of the triad of success at the next lower level, with the trusted core of key actors (the social innovation initiative) morphing into an intermediary support structure at the next lower level. 
The third sector agency delivers viability and independence in the Scottish case, but the business sector is more important in the Serbian case and to a degree in the Austrian case. Nowhere do local businesses appear as dominant players. In the Scottish case, the devolutionary stance of the state and the non-viability of private enterprise in lagging rural areas have left the field for third sector community engagement and new forms of social enterprise. In the Austrian case, local entrepreneurs contribute most actively to the job orientation events, but the professional associations of trades have not sufficiently translated this commitment into institutional support. In Serbia, we face a general weakness of rural businesses. The lack of public support mechanisms assisting social innovations and enterprises constitutes an institutional void, which so far is filled by active financial support provided by foreign donors, the domestic banking sector, as well as financial support by private domestic foundations [26]. The case of the Fenomena Association shows how the establishment of a social innovation, i.e., the establishment of the DAFF fund based on foreign funding, aims to overcome the lack of institutionalized support by operating as a "business angel" for small rural businesses. It also demonstrates that in a context of dire financial needs and weak human capacities, even small amounts of money along with vocational training can already make a difference if civic action steps into the breach.

\subsection{The Triad of Actors May be More or Less Balanced}

The Austrian LAG Zeitkultur acts as both the key intermediary support structure and the creator and promoter of the social innovation initiative Apprentice Worlds. The triad has not found its balance, because the trusted core of key actors and the LAG as the intermediary support structure are actually the same group of people. This imbalance is visualized by the shortness of the edge connecting the two nodes in Figure 3. In Serbia, the absence of relevant intermediary structures in the country is noted. International donors fill that gap, but the benevolent shadow of hierarchy (the SIPRU government unit) depends on them as well [26]. This imbalance is visualized by the shortness of the edge between the two nodes in Figure 5. The triad of actors unfolds itself most evenly in the Scottish initiative, which works in line with the intentions of the Scottish polity. The Community Trust also takes advantage of complementary intermediary support structures, both bottom-up (Association of Community Trusts) and top-down (government agencies, LAG).

\subsection{The Triad is Fractal}

Growth and sustainability of social innovations arguably depend on reliable intermediary support structures. We have seen that intermediary structures are fractal in principle, which means that they may develop additional tiers further down or up: Braemar Community Limited, which nurtures a number of social innovation initiatives locally, is one of 250 members of the Development Trusts Association in Scotland, which represents its interests on a wider scale. The LAG Zeitkultur is member of the Austrian LEADER Forum, a voluntary association that acts as a stakeholder for rural development in Austria. The bottom-up representation of social innovation initiatives in intermediary structures seems to favor fruitful policy dialogue and policy integration. According to the basic tenets of neo-institutionalism [83], organizations depending on dominant supply or support structures tend to assimilate themselves over time, increasingly mirroring their features. This process becomes less damning if the intermediary structures are at least in substantial part delegated from bottom-up, facilitating multi-stakeholder participation and maintaining lively links not only with the public domain but also with global networks of like-minded initiatives, as well as a wider range of stakeholders in the society at large. Partnerships involving civic actors are the beating hearts not only of social innovation initiatives themselves, but also of their institutionalized second or third layers of representation and support. These layers feature "trusted cores of key actors" and polity providing the "shadow of hierarchy" at different scales. 


\subsection{Social Capital and Trust are Depletable Resources}

Where there is less trust and weaker social capital within civil society and between third sector actors and public agency, social innovation is likely to be suppressed [44]. A lack of trust in society for various reasons is often observable as informal institutional voids when it comes to starting businesses [84]. This may be especially the case in post-socialist countries, and in the shadow of the former fifty year-long collectivist organization, may lead to more individualistic responses. Even though the socialist regime in Serbia was softer compared to Soviet socialism, it led to the loss of trust in local, collective self-organization, which just lately has partly been overcome $[26,85]$. Furthermore, the emergence of nationalist-populist regimes in post socialist and western states may further stifle collaborative efforts of citizens and third sector agency to promote alternative ways of doing, particularly if they depend on support structures (international donors) from abroad. Thus, in Serbia we can observe the weak position or stigmatization of civil society organizations, which are often distrusted by the state [26]. The interests of civil society organizations are not highly regarded in public policy discussions, both nationally and locally [86], which makes the political-institutional environment in Serbia the least supportive for "bottom-up" initiatives among our three cases.

\section{Conclusions on the Research Questions}

(i) What are the social and institutional conditions and policy initiatives that foster or hinder social innovation?

The role of a heuristic model is to provide orientation and facilitate the understanding of complex realities in order to become effective for action. The triad of actors reduces real complexity to three groups of relevant actors, their respective strengths, and their mutual connections. The triad captures the relevant factors in the relationships between the trusted core of key actors, the shadow of hierarchy, and intermediary support structures.

(ii) How can policymakers encourage, enable, and promote social innovation, and utilize social innovation to achieve better results in developing rural areas?

Trust in institutions and a societal climate in which individual self-expression, civic action, and community empowerment are considered as intrinsic values are paramount for social innovation to thrive. Thus, institutional policies provide the matrix for civic action, entrepreneurship, and public interventions, such as constitutional laws on basic rights, or legislation on cooperatives, public-private partnerships, and governance arrangements in general.

Sectoral policies regulate a particular thematic field (childcare, elderly care, environmental or heritage site protection, energy provision, etc.) Structural policies are cross-sectoral and oriented towards cohesion objectives (such as local and regional development, employment and income distribution, and the provision of basic infrastructures and services). At first sight, structural policies appear most propitious as flexible entry points for providing need-specific and flexible funding and advisory instruments, such as Local Action Groups, local helpdesks, or one-stop-shops for social innovation initiatives. However, due to various reasons, structural policies sometimes do not live up to these expectations, whereas sectoral policies may provide specialized support that can be integrated and customized by the local initiative. The most successful social innovations seem to be those feeding off all three policy dimensions: the sectoral, the structural, and the institutional dimension.

Even if structural and sectoral policy provisions ensure need-based and flexible support, meeting a broad variety of challenges in various types of territories, the over-determination of policies may constitute a hindrance to supporting local social innovation. Provision for ring-fenced funds for social innovation in sectoral and structural policies can create the possibility space for anything that was not imagined, maybe not even imaginable in the times when a policy, a political strategy, or program had been designed. These ring-fenced funding opportunities should be made known and accessible for anyone interested and in search of support.

Social innovation will achieve most when the triadic relationships between the state, intermediary organizations, and local actors are working together synergistically. On occasion, this may happen 
fortuitously. Where it is designed into policies at multiple scales, it is more likely to deliver positive societal outcomes.

The increasing recognition of the idea and factual role of social innovation should be translated into the design and promotion of political goals. Global policy objectives, such as the Sustainable Development Goals of the UN Agenda 2030, but also the European Green Deal stipulating carbon-neutrality until 2050, will have to lay strong emphasis on social innovation, which means nurturing an innovative ecosystem with inclusive institutions and empowered local communities. Starting at the local level will help generate momentum, which leads to growing public awareness of novel solutions, bringing forth new forms of organization in response to policy gaps and market failure, eventually leading to regime shifts at society level.

Our triad model has been shown to be useful for analyzing the role of policies and political frameworks for social innovation initiatives. It not only appears to be a helpful frame to describe the relevant actors and their relations, it also provides an analytical model for the assessment of how well the political system supports social innovations and how the political support may be improved.

The authors consider the first validation of the heuristic model as promising. It allows for an analysis of weaknesses and gaps in the political support of social innovations and provides entrance points for improvements. As a next step, further refinement of the model and its operationalization into an integrated assessment grid serving policy makers and advisers are recommended. As the model is agent-based and potentially applicable in all types of territories, the authors think that it should also be applied and tested in case studies on social innovation in urban areas.

Author Contributions: Conceptualization, R.L. and G.W.; methodology, R.L., A.L., B.S. and G.W.; formal analysis, R.L., B.S. and I.Ž.; investigation, R.L., B.S. and I.Ž.; writing—original draft preparation, R.L.; writing-review and editing, R.L., B.S., G.W., A.L. and I.Ž.; visualization, R.L. All authors have read and agreed to the published version of the manuscript.

Funding: This research received funding by the European Union's Horizon 2020 research and innovation programme under Grant Agreement No 677622 and the EU Rural Development Programme 2014-2020 in Austria for the SILEA project. Open access funding was provided by BOKU Vienna Open Access Publishing Fund.

Acknowledgments: The research was mainly conducted within the European Union's Horizon 2020 research and innovation project SIMRA (Social Innovation in Marginalised Rural Areas). SIMRA has produced a rich treasure of conceptual models and empirical insights, which allow for a fresh look at the interactions between social innovation from bottom-up and political frameworks and policies from top-down. The authors thank the SIMRA case study authors, particularly those which have delivered the groundwork for the SIMRA cross-case analysis report (Ravazzoli et al. 2019). Our gratitude extends to all other contributors to the SIMRA project, to those responsible for Work Packages and Tasks and their collaborators, likewise to the research team of the SILEA project, to anybody involved in the case studies in Austria, Serbia, and the UK, and ultimately, first and foremost, to all the courageous people out there looking for solutions and striving for the best for the people they care about, the society at large, and for us all.

Conflicts of Interest: The authors declare no conflict of interest.

\section{References}

1. Berger, W.F. Innovation als Sozialer Prozess am Beispiel Neo-Endogener Regionalentwicklung in der Europäischen Union. Ph.D. Thesis, Karl-Franzens-Universität Graz, Graz, Austria, 2017.

2. Beer, A.; Lester, L. Institutional thickness and institutional effectiveness: Developing regional indices for policy and practice in Australia. Reg. Stud. Reg. Sci. 2015, 2, 205-228. [CrossRef]

3. European Commission. Vision and Trens of Social Innovation in Europe; DG Research and Innovation of the EC: Luxembourg, 2017.

4. Neumeier, S. Social innovation in rural development: Identifying the key factors of success. Geogr. J. 2017, 183, 34-46. [CrossRef]

5. Mosdale, L.; Slee, B. Social Innovation: A Must-Have for Marginalised Rural Areas. ARC 2020 Web Resource. 2020. Available online: https://www.arc2020.eu/social-innovation-a-must-have-for-marginalised-ruralareas/ (accessed on 10 August 2020). 
6. SIMRA—Social Innovation in Marginalized Rural Areas, EU Horizon 2020 Project, GA Nr. 677622. Available online: http://www.simra-h2020.eu (accessed on 10 August 2020).

7. Ludvig, A.; Rogelja, T.; Asamer-Handler, M.; Weiss, G.; Wilding, M.; Živojinović, I. Governance of Social Innovation in Forestry. Sustainability 2020, 12, 1065. [CrossRef]

8. Kluvankova, T.; Gežik, V.; Špaček, M.; Brnkaláková, S.; Slee, B.; Polman, N.; Valero, D.; Bryce, R.; Alkhaled, S.; Secco, L.; et al. Transdisciplinary Understanding of SI in MRAs. Report D2.2. Social Innovation in Marginalised Rural Areas Project (SIMRA). 2017. Available online: http://www.simra-h2020.eu/index.php/deliverables/ (accessed on 7 September 2020).

9. Secco, L.; Pisani, E.; Burlando, C.; Da Re, R.; Gatto, P.; Pettenella, D.; Vassilopoulus, A.; Akinsete, E.; Koundouri, P.; Lopolito, A.; et al. Set of Methods to Assess SI Implications at Different Levels: Instructions for WPs 5E6. Report D4.2. Social Innovation in Marginalised Rural Areas Project (SIMRA). 2017. Available online: http://www.simra-h2020.eu/index.php/deliverables/ (accessed on 7 September 2020).

10. Secco, L.; Pisani, E.; Da Re, R.; Rogelja, T.; Burlando, C.; Vicentini, K.; Pettenella, D.; Masiero, M.; Miller, D.; Nijnik, M. Towards a method of evaluating social innovation in forest-dependent rural communities: First suggestions from a science-stakeholder collaboration. For. Policy Econ. 2019, 104, 9-22. [CrossRef]

11. Secco, L.; Pisani, E.; Da Re, R.; Vicentini, K.; Rogelja, T.; Burlando, C.; Ludvig, A.; Weiss, G.; Živojinović, I.; Górriz-Mifsud, E.; et al. Manual on Innovative Methods to Assess SI and its Impacts. Report D4.3. Social Innovation in Marginalised Rural Areas Project (SIMRA). 2019. Available online: http://www.simra-h2020. eu/index.php/deliverables/ (accessed on 7 September 2020).

12. Górriz-Mifsud, E.; Marini Govigli, V.; Ravazzoli, E.; Dalla Torre, C.; Da Re, R.; Secco, L.; Pisani, E.; Ludvig, A.; Weiss, G.; Akinsete, E.; et al. Case Study Protocols and Final Synthetic Description for Each Case Study. Report D5.1. Social Innovation in Marginalised Rural Areas Project (SIMRA). 2018, p. 158. Available online: http://www.simra-h2020.eu/index.php/deliverables/ (accessed on 7 September 2020).

13. Marini Govigli, V.; Melnykovych, M.; Górriz-Mifsud, E.; Dalla Torre, C.; Ravazzoli, E.; Da Re, R.; Pisani, E.; Secco, L.; Vincentini, K.; Ludvig, A.; et al. Report on Social Innovation Assessment in Each Selected Case Study. Report D5.3. Social Innovation in Marginalised Rural Areas Project (SIMRA). 2019. Available online: http://www.simra-h2020.eu/index.php/deliverables/ (accessed on 7 September 2020).

14. Ravazzoli, E.; Dalla Torre, C.; Streifeneder, T.; Pisani, E.; Da Re, R.; Vicentini, K.; Secco, L.; Górriz-Mafsud, E.; Marini Govigli, V.; Melnykovych, M.; et al. Final Report on Cross-Case Studies Assessment of Social Innovation. Report D5.4. Social Innovation in Marginalised Rural Areas Project (SIMRA). 2020, p. 119. Available online: https://bia.unibz.it/handle/10863/14724 (accessed on 7 September 2020).

15. Weiss, G.; Ludvig, A.; Lukesch, R. Relationships between Policy and Social Innovation. In Final Report on Cross-Case Studies Assessment of Social Innovation; Ravazzoli, E., Dalla Torre, C., Streifeneder, T., Pisani, E., Da Re, R., Vicentini, K., Secco, L., Górriz-Mifsud, E., Marini Govigli, V., Melnykovych, M., et al., Eds.; Report D5.4. Social Innovation in Marginalised Rural Areas Project (SIMRA); 2020; pp. 69-84. Available online: https://bia.unibz.it/handle/10863/14724 (accessed on 7 September 2020).

16. Ludvig, A.; Weiss, G.; Živojinović, I.; Nijnik, M.; Miller, D.; Barlagne, C.; Perlik, M.; Hermann, P.; Egger, T.; Dalla Torre, C.; et al. Political Framework Conditions, Policies and Instruments for SIs in Rural Areas. Report D6.1. Social Innovation in Marginalised Rural Areas Project (SIMRA). 2017. Available online: http: //www.simra-h2020.eu/index.php/deliverables/ (accessed on 7 July 2020).

17. Ludvig, A.; Weiss, G.; Sarkki, S.; Nijnik, M.; Živojinović, I. Mapping European and forest related policies supporting social innovation for rural settings. For. Policy Econ. 2018, 97, 146-152. [CrossRef]

18. Ludvig, A.; Weiss, G.; Živojinović, I.; Nijnik, M.; Miller, D.; Barlagne, C.; Dijkshoorn-Dekker, M.; Jack, S.; Al Khaled, S.; Polman, N.; et al. Policy Implications for Social Innovation in Marginalized Rural Areas. Report D6.2. Social Innovation in Marginalised Rural Areas Project (SIMRA). 2018. Available online: http://www.simra-h2020.eu/index.php/deliverables/ (accessed on 25 August 2020).

19. Slee, B. Social innovation in community energy in Scotland: Institutional form and sustainability outcomes. Glob. Transit. 2020, 2, 157-166. [CrossRef]

20. Slee, B.; Mosdale, L. How policy can help bring about social innovation in rural areas. In Policy Brief; 2020; p. 16. Available online: http://www.simra-h2020.eu/wp-content/uploads/2020/02/2020-02-03-Policy-brief Slee-Mosdale_FINAL.pdf (accessed on 25 August 2020). 
21. Lukesch, R.; Dalla Torre, C.; Valero, D.; Ravazzoli, E. Conclusions. In Final Report on Cross-Case Studies Assessment of Social Innovation; Ravazzoli, E., Dalla Torre, C., Streifeneder, T., Pisani, E., Da Re, R., Vicentini, K., Secco, L., Górriz-Mifsud, E., Marini Govigli, V., Melnykovych, M., et al., Eds.; Report D5.4. Social Innovation in Marginalised Rural Areas Project (SIMRA); 2019; pp. 98-103. Available online: https://bia.unibz.it/handle/ 10863/14724 (accessed on 7 September 2020).

22. Lukesch, R.; Ecker, B.; Fidlschuster, L.; Fischer, M.; Gassler, H.; Mair, S.; Philipp, S.; Said, N. Analyse der Potenziale Sozialer Innovation im Rahmen von LEADER 2014-2020; ÖAR and ZSI: Wien, Austria, 2019.

23. Butzin, A.; Widmaier, B. Exploring Knowledge Dynamics through Innovation Biographies. Reg. Stud. 2016, 50, 220-232. [CrossRef]

24. Slee, B. Analytical-Informational Case Studies (Case Study Type B/C): Braemar and Huntly Community Energy Projects; Report 5.4q. Internal project report. Social Innovation in Marginalised Rural Areas (SIMRA); 2019.

25. Secco, L.; Da Re, R.; Pisani, E.; Ludvig, A.; Weiss, G.; Górriz-Mifsud, E.; Marini Govigli, V. Compilation of Tools for Data Collection for SIMRA Pioneer and Regular Case Studies. Report 5.1, Social Innovation in Marginalised Rural Areas (SIMRA). 2018. Available online: http://www.simra-h2020.eu/index.php/deliverables/ (accessed on 7 September 2020).

26. Živojinović, I.; Ludvig, A.; Hogl, K. Social Innovation to Sustain Rural Communities: Overcoming Institutional Challenges in Serbia. Sustainability 2019, 11, 7248. [CrossRef]

27. Polanyi, K. The Great Transformation; Beacon Press: Boston, MA, USA, 2001; (original publishing year: 1944).

28. Giddens, A. Central Problems in Social Theory; MacMillan Publishers Ltd.: London, UK, 1979.

29. Schumpeter, J. Capitalism, Socialism and Democracy; Harper and Brothers: New York, NY, USA, 1942.

30. Drucker, P. Innovation and Entrepreneurship. Practice and Principles; Harper Business (Reprint): New York, NY, USA, 2006; (original publishing year: 1985).

31. Polman, N.; Slee, B.; Kluvánková, T.; Dijkshoorn, M.; Nijnik, M.; Gezik, V.; Soma, K. Classification of Social Innovations for Marginalized Rural Areas. Report D2.1. SIMRA. 2017. Available online: http://www.simra-h2020. eu/wp-content/uploads/2017/09/D2.1-Classification-of-SI-for-MRAs-in-the-target-region.pdf (accessed on 7 July 2020).

32. Millard, J. How Social Innovation Underpins Sustainable Development. In Atlas of Social Innovation; TU Dortmund University: Dortmund, Germany, 2017; pp. 40-43. Available online: https:/www.socialinnovationatlas.net/fileadmin/PDF/ einzeln/01_SI-Landscape_Global_Trends/01_07_How-SI-Underpins-Sustainable-Development_Millard.pdf (accessed on 7 July 2020).

33. Nichol, M. Social vs. Societal, Web Resource (Daily Writing Tips). 2012. Available online: https://www. dailywritingtips.com/social-vs-societal/ (accessed on 7 July 2020).

34. Grimm, R.; Fox, C.; Baines, S.; Albertson, K. Social innovation, an answer to contemporary challenges? Locating the concept in theory and practice. Innov. Eur. J. Soc. Sci. Res. 2013, 26, 436-455. [CrossRef]

35. Bemelmans-Videc, M.-L.; Rist, R.C.; Vedung, E. Carrots, Sticks E Sermons: Policy Instruments and Their Evaluation; Transaction Publishers: New Brunswick, NJ, USA, 2003.

36. Bateson, G. Mind and Nature: A Necessary Unity; E.P. Dutton: New York, NY, USA, 1979.

37. Maturana, H.; Varela, F. The Tree of Knowledge: The Biological Roots of Human Understanding; Shambala: Boston, MA, USA, 1987.

38. Prigogine, I.; Stengers, I. Order out of Chaos: Man's New Dialogue with Nature; Bantam Books: New York, NY, USA, 1984.

39. Giddens, A. The Constitution of Society: Outline of the Theory of Structuration; Polity Press: Cambridge, UK, 1984.

40. Huntington, S.P. Political Order in Changing Societies; Yale University Press: New Haven, CT, USA, 1968.

41. Penven, A. Recognition and Institutionalisation of Social Innovations in the Field of Social Policy. Innovations 2015, 3, 129-150. [CrossRef]

42. Ostrom, E.; Walker, J. Trust and Reciprocity. Interdisciplinary Lessons from Experimental Research; Russell Sage Foundation Series on Trust; Russell Sage Foundation: New York, NY, USA, 2003; Volume VI.

43. Luhmann, N. Soziale Systeme: Grundriss Einer Allgemeinen Theorie; Suhrkamp: Frankfurt, Germany, 1984.

44. Putnam, R.D. The Prosperous Community. Am. Prospect 1993, 4, 35-42.

45. Alter, N. On ne peut pas institutionnaliser l'innovation. In L'innovation Sociale. Émergence et Effets sur la Transformation des Sociétés; Klein, J.L., Harrison, D., Eds.; Presses de 1'Université de Québec: Quebec City, QC, Canada, 2007; pp. 173-192.

46. Heiland, K. Kontrollierter Kontrollverlust. Jazz und Psychoanalyse; Psychosozial-Verlag: Giessen, Germany, 2016. 
47. Geels, F.W.; Schot, J. The dynamics of transitions: A socio-technical perspective. In Transitions to Sustainable Development: New Directions in the Study of Long Term Transformative Change; Grin, J., Rotmans, J., Schot, J., Eds.; Routledge: New York, NY, USA, 2010.

48. Lukesch, R. Policy Recommendations from the SIMRA Project. In Proceedings of the SIMRA Conference: Social Innovators in Rural Areas, Bruxelles, Belgium, 19 February 2020.

49. Domanski, D.; Kaletka, C. Lokale Ökosysteme sozialer Innovation verstehen und gestalten. In Soziale Innovationen Lokal Gestalten; Franz, H.W., Kaletka, C., Eds.; Springer VS: Wiesbaden, Germany, 2018; pp. 291-308.

50. Chapman, J. System Failure. In Why Governments Must Learn to Think Differently; DEMOS: London, UK, 2002.

51. Isaksen, A.; Trippl, M. Innovation in space. The mosaic of regional development patterns. Oxf. Rev. Econ. Policy 2017, 33, 122-140. [CrossRef]

52. Acemoglu, D.; Robinson, J.A. Why Nations Fail; Profile Books: Croydon, UK, 2012.

53. Acemoglu, D.; Robinson, J.A. The Narrow Corridor; Pengiun Press: New York, NY, USA, 2019.

54. Mulgan, G.; Albury, D. Innovation in the Public Sector; Strategy Unit, UK Cabinet Office, UK Government: London, UK, 2003.

55. Rametsteiner, E.; Bauer, A.; Weiss, G. Policy Integration and Coordination: Theoretical, Methodical and Conceptual Approach. In Policy Integration and Coordination: The Case of Innovation and the Forest Sector in Europe, 15; Rametsteiner, E., Weiss, G., Ollonqvist, P., Slee, B., Eds.; OPOCE: Brussels, Belgium, 2010.

56. Steurer, R.; Berger, G. Horizontal policy integration: Concepts, administrative barriers and selected practices. In Nachhaltigkeit regieren: Eine Bilanz zu Governance-Prinzipien und -Praktiken [Governing Sustainability: Taking Stock of Governance Principles and Practices]; Steurer, R., Trattnigg, R., Eds.; Oekom: München, Germany, 2010; pp. 55-74.

57. Mulgan, G. Ready or not? Taking Innovation in the Public Sector Seriously; NESTA Provocation 03 April 2007; NESTA: London, UK, 2007.

58. Murray, R.; Caulier-Grice, J.; Mulgan, G. The Open Book of Social Innovation-The Young Foundation; NESTA: London, UK, 2010.

59. Weiss, C.H. Have we learned anything new about the use of evaluation? Am. J. Eval. 1998, 19, 21-33. [CrossRef]

60. Barlagne, C.; Melnykovych, M.; Hewitt, R.; Nijnik, M. Analytical Case Studies (Case Study Type A) Lochcarron Community Development Company—Strathcarron, Scotland, UK (led by HUTTON); Report 5.4j. Internal project report. Social Innovation in Marginalised Rural Areas (SIMRA); 2019.

61. Rodríguez Fernández-Blanco, C.; Górriz-Mifsud, E.; Marini Govigli, V.; Prokofieva, I. Analytical Case Studies (Case Study Type A) Forest Fire Volunteer Groups-Catalonia, Spain (CTFC); Report 5.4a. Internal project report. Social Innovation in Marginalised Rural Areas (SIMRA); 2019.

62. Dalla Torre, C.; Gramm, V.; Lollini, M.; Ravazzoli, E. Analytical Case Studies (Case Study Type A) Learning, Growing, Living with Women Farmers-South Tyrol, Italy (EURAC); Report 5.4d. Internal project report. Social Innovation in Marginalised Rural Areas (SIMRA); 2019; p. 59.

63. Dargan, L.; Shucksmith, M. LEADER and Innovation. Sociol. Rural. 2008, 48, 274. [CrossRef]

64. Slee, B. A personal journey through the policy maze: Alford and District Men's Shed. In Proceedings of the SIMRA SITT meeting in Aberdeen, Aberdeen, UK, 14-17 October 2019.

65. Melnykovych, M.; Dijkshoorn-Dekker, M.; Polman, N. Analytical Case Studies (Case Study Type A) Care Farm Pitteperk-The Netherlands (led by DLO); Report 5.4c. Internal project report. Social Innovation in Marginalised Rural Areas (SIMRA); 2019.

66. Melnykovych, M.; Kozova, M.; Spacek, M.; Kluvankova, T. Analytical Case Studies (Case Study Type A) Revitalising Plans for Vlkolinec-Slovakia (Led by IFE SAS/CETIP); Report 5.4k. Internal project report. Social Innovation in Marginalised Rural Areas (SIMRA); 2019.

67. GIZ. Cooperation Management for Practitioners. Managing Social Change with Capacity WORKS; Springer Gabler: Wiesbaden, Germany, 2015.

68. Pisani, E.; Franceschetti, G.; Secco, L.; Christoforou, A. (Eds.) Social Capital and Local Development. From Theory to Empirics; Palgrave Macmillan Springer Nature: Cham, Switzerland, 2019.

69. Esslinger, E.; Schlechtriemen, T.; Schweitzer, D.; Zons, A. Die Figur des Dritten. Ein kulturwissenschaftliches Paradigma; Suhrkamp/Insel: Berlin, Germany, 2010.

70. Rajan, R. The Third Pillar. How Markets and the State Leave the Community Behind; Penguin Random House: New York, NY, USA, 2019. 
71. Marini Govigli, V.; Vassilopoulos, A.; Akinsete, E. Analytical Case Studies (Case Study Type A) A Box of Sea-Lesvos and Leros, Greece (ICRE8); Report 5.4i. Internal project report. Social Innovation in Marginalised Rural Areas (SIMRA); 2019.

72. Melnykovych, M.; Labidi, A.; Chorti, H.; Bengoumi, M. Analytical Case Studies (Case Study Type A) Supporting Dairy Producers Organisations through a Public-Private Partnership Programme-Tunisia (led by FAOSNE); Report 5.4h. Internal project report. Social Innovation in Marginalised Rural Areas (SIMRA); 2019.

73. Marini Govigli, V.; Lopolito, A.; Baselice, A.; Prosperi, M. Analytical Case Studies (Case Study Type A) VAZAPP'-Apulia, Italy (UNIFG); Report 5.4g. Internal project report. Social Innovation in Marginalised Rural Areas (SIMRA); 2019.

74. Ludvig, A.; Corradini, G.; Asamer-Handler, M.; Pettenella, D.; Verdejo, V.; Martínez, S.; Weiss, G. The practice of innovation: The role of institutions in support of Non-Wood Forest Products. BioProducts Bus. 2016, 6, 73-84.

75. Weiss, G.; Ludvig, A.; Živojinović, I.; Asamer-Handler, M.; Huber, P. Non-timber innovations: How to innovate in side-activities of forestry-Case Study Styria, Austria. Austrian J. For. Sci. 2017, 134, 231-250.

76. Churchman, C.W. Wicked Problems. Manag. Sci. 1967, 14, 141-146.

77. Rittel, H.W.J.; Webber, M.M. Dilemmas in a general theory of planning. Policy Sci. 1973, 4, 155-169. [CrossRef]

78. Jelinčić, D.A. Innovations in Culture and Development: The Culturinno Effect in Public Policy; Palgrave Macmillan: London, UK, 2017.

79. Brown, K. Innovations for conservation and development. Geogr. J. 2002, 168, 6-17. [CrossRef]

80. Scharpf, F.W. Games Real Actors Can Play: Actor-Centered Institutionalism in Policy Research; Westview Press: Boulder, CO, USA, 1997.

81. Servillo, L. Tailored polities in the shadow of the state's hierarchy. The CLLD implementation and a future research agenda. Eur. Plan. Stud. 2019, 27, 678-698. [CrossRef]

82. Butkeviciene, E. Social innovation in rural communities: Methodological framework and empirical evidence. Soc. Sci. 2009, 1, 80-88.

83. Hasse, R.; Krücken, G. Neo-institutionalistische Theorie. In Handbuch Soziologische Theorien; Kneer, G., Schroer, M., Eds.; VS Verlag für Sozialwissenschaften: Wiesbaden, Germany, 2009. [CrossRef]

84. Webb, J.W.; Khoury, T.A.; Hitt, M.A. The influence of formal and informal institutional voids on entrepreneurship. Entrep. Theory Pract. 2019. [CrossRef]

85. Marinović, N. Social Enterprise Ecosystem in Serbia. In Social Enterprise Ecosystems in Croatia and the Western Balkans; Etchart, N., Varaga, A., Eds.; A Mapping Study of Albania, Bosnia \& Herzegovina, Croatia, Kosovo, North Macedonia, Montenegro and Serbia, Chapter 13; NESsT: San Leandro, CA, USA, 2017; pp. 191-223. Available online: http://connecting-youth.org/publications/publikim19.pdf (accessed on 23 July 2020).

86. BTI. Serbia Country Report; Bertelsmann Stiftung: Gütersloh, Germany, 2018; Available online: https: //www.bti-project.org/en/reports/country-dashboard-SRB.html (accessed on 23 July 2020). 